\title{
VASCULAR PLANTS OF THE RIVERINE PLAIN OF NEW SOUTH WALES WITH NOTES ON DISTRIBUTION AND PASTORAL USE
}

J.H. LeIGH* and W.E. MULham

(Accepted September 1976)

\section{ABSTRACT}

Leigh, J.H. (CSIRO Division of Plant Industry, Canberra, Australia) and Mulham, W.E. (CSIRO Division of Land Resources Management, Deniliquin, Australia) 1977. Vascular plants of the Riverine Plain of New South Wales with notes on distribution and forage value. Telopea 1 (4): 225-291 (1977). - An enumeration of plants collected on the Riverine Plain is presented. The list includes plants collected by the authors in this semi-arid region of southern New South Wales over a fifteen-year period together with specimens lodged by other collectors at the National Herbarium of New South Wales, Sydney. Identification of the plants was carried out by taxonomists at the latter herbarium and voucher specimens are held either at this herbarium or at the CSIRO Riverina Laboratory, Deniliquin. Notes on the occurrence and forage value of each plant are included as well as a short description of the Riverine Plain and its vegetation.

\section{INTRODUCTION}

In 1965 an illustrated manual dealing with 270 of the more common grasses, forbs and small shrubs found on the Riverine Plain was published (Leigh and Mulham 1965). During the collection of material for that book and since that time, we have continued to collect specimens and make notes on species collected. Sources of reference to species we have not collected include relevant files of the New South Wales Department of Agriculture and the Soil Conservation Service of New South Wales, and publications of the National Herbarium of New. South Wales, Sydney. Species are included in this list only where a specimen, identified by staff of the latter herbarium, is held either at the CSIRO Riverina Laboratory, Deniliquin, or at the National Herbarium of New South Wales. In this list specimens held at the Riverina Laboratory are followed by the abbreviation Den.; those held only at the National Herbarium are followed by NSW.

The abbreviations indicate the existence of a specimen which could, if required, be used to check the plant's specific name. It does not necessarily indicate that this is the only specimen held.

We do not claim this list to be exhaustive, nor do we claim to have included all specimens collected from the Riverine Plain and retained at the National Herbarium.

\section{PREVIOUS BOTANICAL COLLECTIONS}

Previous lists of plants collected on the Riverine Plain have been compiled only in as much as they have represented part of broad ecological surveys in which the Plain, or a portion of it, has been included.

Turner (1904) listed plants which he (and others) collected in south-western New South Wales, the area covered stretching from Albury almost to the South Australian border, and from the Murray River to just north of Ivanhoe. No information on distribution of individual species was included.

Beadle (1948) carried out a vegetation survey which covered all that portion of New South Wales west of an approximate line between Tocumwal on the Murray River to Mungindi on the Queensland border. Distribution of pasture species was listed in terms of presence within a number of vegetation associations. (In his unpublished D.Sc. thesis, Beadle also listed the occurrence of species on a county basis).

\footnotetext{
* CSIRO Division of Plant Industry, P.O. Box 1600, Canberra City, A.C.T. 2601.

$\uparrow$ CSIRO Division of Land Resources Management, Riverina Laboratory, Private Bag, P.O., Deniliquin, N.S.W. 2710.
} 
Moore's survey $(1953 a, 1953 b)$ of the south-eastern Riverina included portion of the south-eastern section of the Riverine Plain. Descriptive lists of species in relatively small study areas have been published by Williams (1955) and by Warren Wilson and Leigh (1964).

Although no published information is available, special mention should be made of the specimens collected by Miss E. Officer of "Zara", Wanganella, soon after the turn of the century. The National Herbarium of New South Wales has retained a great number of these specimens and, since many of the species are now either very rare or possibly extinct on the Riverine Plain, they form a valuable record.

\section{ACKNOWLEDGEMENTS}

In the compilation of this list over the last decade the authors have become indebted to a number of people for assistance in many diverse ways. We are grateful to Dr L.A.S. Johnson, Director of the National Herbarium of New South Wales, for permission to use the facilities at the Herbarium on several occasions, and to his staff, who have been extremely co-operative and helpful in the botanical determinations of specimens, the checking of nomenclature and the preparation of this list for publication. Acknowledgement is made of the assistance given by the staff of the Herbarium Australiense, Canberra, in checking specimens expected to be held there. To various officers of the New South Wales Department of Agriculture and the Soil Conservation Service of New South Wales we tender our thanks for their permission to peruse their files. Our thanks are also due to colleagues and other interested persons for the occasional specimen of previously uncollected plants and for their drawing attention to errors and omissions. Mr O.B. Williams, now of the Division of Land Resources Management, Canberra, formerly of the Division of Plant Industry, initiated the collection of plants at the Riverina Laboratory.

\section{ARRANGEMENT}

Families have been arranged in the order adopted by the National Herbarium of New South Wales in the "Flora of New South Wales" with the exception of the Pteridophyta which we have placed before the Gymnospermae. For convenience, genera and species have been listed in alphabetical order within their families.

Introduced species (marked with an asterisk) have been included only where these have become naturalized, i.e. are able to persist in the natural environment either as perennials, or, in the case of annuals, by regeneration from seed.

Information regarding palatability, poisonous characteristics etc. has been included where known. The use of the term "palatable" is an indication that a plant is eaten by domestic stock in the normal grazing situation.

\section{THE RIVERINE PLAIN}

The Riverine Plain of south-eastern Australia is a depositional landform developed from prior streams and ancestral rivers which were functional during quite different conditions of climate and hydrology from those which prevail at the? present time. The geomorphology and hydrology of the Plain, which extends over an appreciable area of Victoria and New South Wales $(68,000 \mathrm{sq} \mathrm{km})$ - see Figure 1, has been described by Butler 1950; Pels 1964; Stannard 1968; and Leigh and Noble 1972. In brief, it is an alluvial plain of gently sloping fans which issue from three major river valleys in the eastern highlands. The gradient of the Plain decreases from about 1 in 3,000 near the hills to less than 1 in 5,000 at the western limit. 


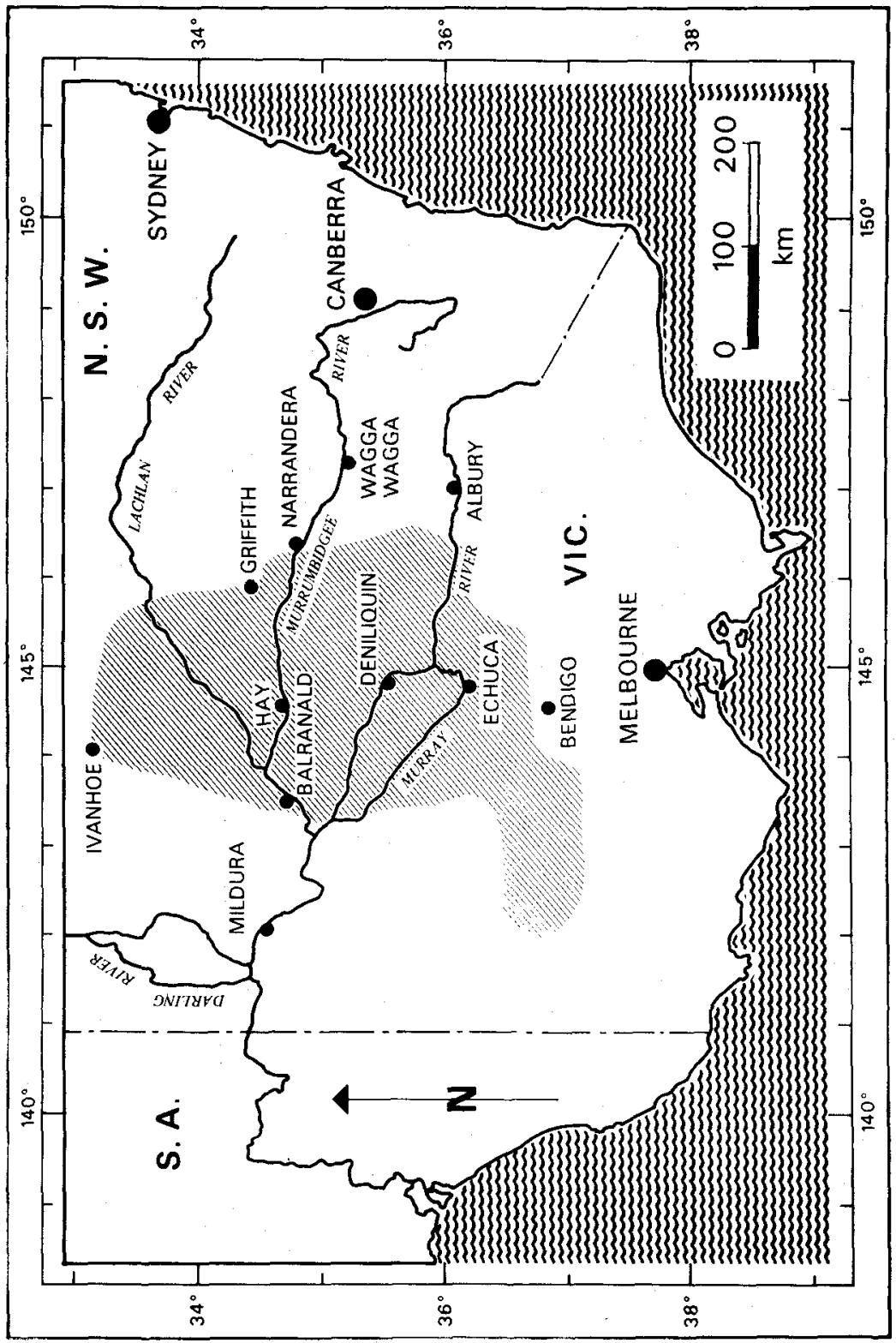

Figure 1.-The Riverine Plain of south-eastern Australia. [From Leigh and Noble (1972) after Butler (1950)]. Plants included in this checklist were collected only from that portion of the Plain north of the Murray River. 


\section{THE AREA}

The area covered by this list extends over that part of the Riverine Plain north of the Murray River. It is the part of the Plain with which the authors have become familiar during the course of their activities in semi-arid research based at Deniliquin, New South Wales.

To the west, north and north-east the boundary of this area is delineated by the abrupt and conspicuous change from the flat, relatively treeless plains to the more elevated lighter soils of the mallee and belah-rosewood vegetation. In the southeast, where there is no such obvious demarcation, the boundary is the road from Barooga through Berrigan and Jerilderie to Narrandera.

\section{THE VEGETATION}

The vegetation of the Riverine Plain of New South Wales has been described by a number of authorities (Beadle 1948; Moore 1953a, 1953b; Williams 1955, 1956, 1961, 1966, 1968a, 1968b; Stannard 1963; Warren Wilson and Leigh 1964; Leigh and Noble 1972). Three formations (sclerophyll forest; woodland; shrub steppe) are recognized, comprising six subformations and alliances and eleven associations. The groupings of these climax vegetational communities are listed in Table 1 and the distribution of the alliances is depicted in Figure 2. In broad terms the vegetational formations progress in bands parallel to the isohyets from dry sclerophyll forest at the foothill section (annual rainfall $450 \mathrm{~mm}$ ) through savannah woodland $(350-450 \mathrm{~mm})$ to shrub steppe $(290-350 \mathrm{~mm})$. Eucalypt forest and eucalypt woodland communities border the permanent water courses, drainage lines and low-lying areas.

TABLE 1. GROUPING OF CLIMAX VEGETATION COMMUNITIES WITHIN THE RIVERINE PLAIN

\begin{tabular}{|c|c|c|c|}
\hline FORMATION & SUBFORMATION & ALLIANCE & ASSOCIATION \\
\hline Sclerophyll forest & $\begin{array}{l}\text { Closed Swamp, Sclerophyll } \\
\text { Forest and } \\
\text { Woodland }\end{array}$ & Eucalyptus camaldulensis & E. camaldulensis \\
\hline Woodland & $\begin{array}{l}\text { Tall Woodland } \\
\text { Shrub Woodland } \\
\text { Savannah Woodland }\end{array}$ & $\begin{array}{l}\text { Eucalyptus microcarpa } \\
\text { Acacia pendula-Atriplex } \\
\text { nummularia } \\
\text { Eucalyptus largiflorens }\end{array}$ & $\begin{array}{l}\text { E. microcarpa } \\
\text { E. microcarpa-Callitris } \\
\text { columellaris } \\
\text { E. microcarpa-C. columellaris } \\
\text { A. pendula-A. nummularia } \\
\text { E. largiflorens }\end{array}$ \\
\hline Shrub Steppe & $\begin{array}{l}\text { Saltbush Steppe } \\
\text { Bluebush Steppe }\end{array}$ & $\begin{array}{l}\text { Atriplex vesicaria } \\
\text { Maireana pyramidata }\end{array}$ & $\begin{array}{l}\text { A. vesicaria } \\
\text { A. vesicaria-Maireana aphylla } \\
\text { A. nummularia } \\
\text { Muehlenbeckia cunninghamii } \\
\text { Maireana pyramidata }\end{array}$ \\
\hline
\end{tabular}

In some parts, particularly in the northern and western districts, outliers of mallee eucalypt shrubland (Eucalyptus spp.) and belah-rosewood shrub woodland (Casuarina cristata-Heterodendrum oleifolium) protrude into the Riverine Plain proper. Species from these communities are not included in this list since the communities are regarded as being atypical for the Plain.

The following is a brief account of the three formations and constituent alliances and associations referred to above as they occur within the Riverine Plain of New South Wales. More detail is given in Leigh and Noble (1972). 


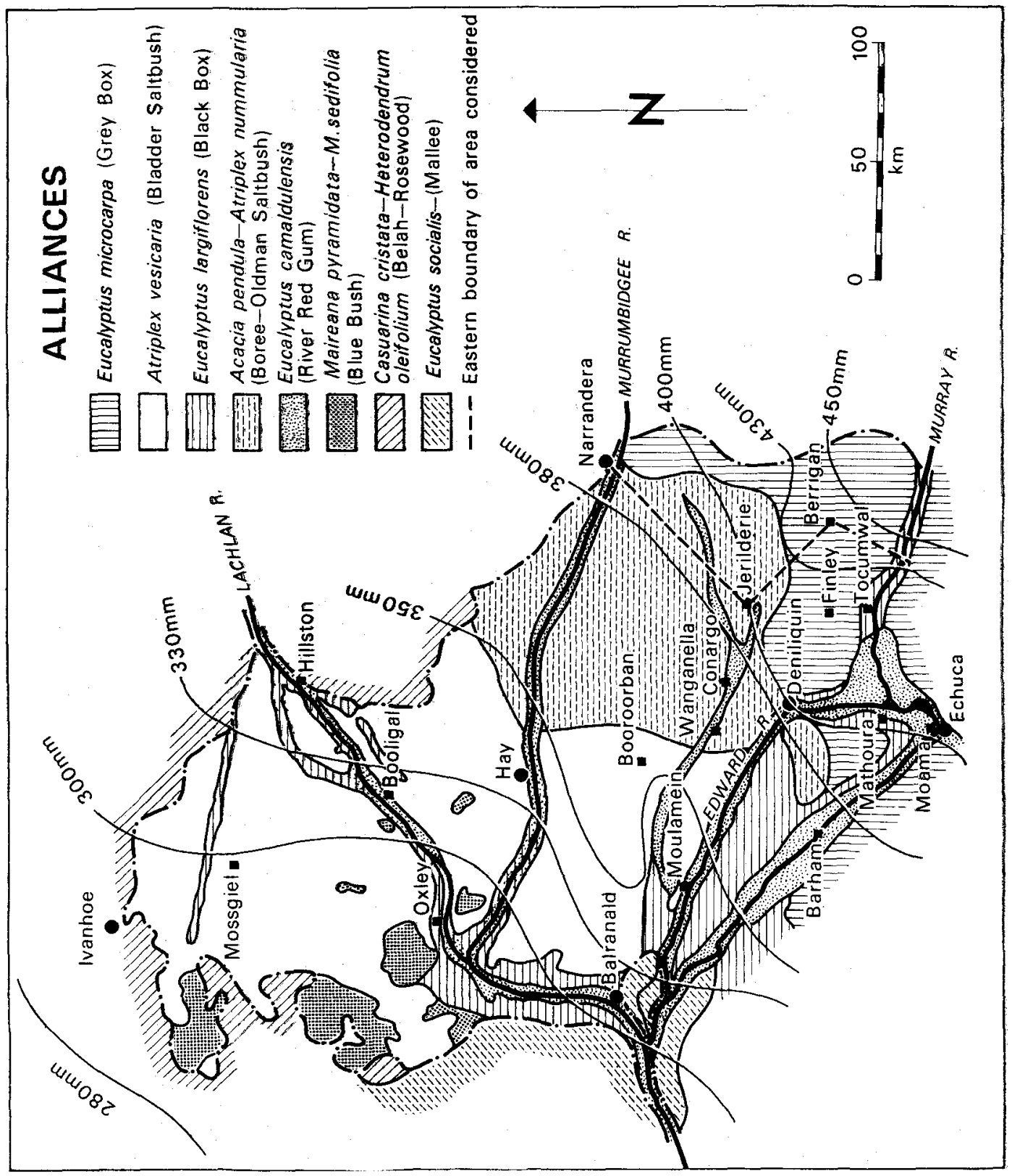

Figure 2.-The distribution of the principal vegetation alliances on the Riverine Plain (rainfall isohyets shown in millimetres). (After Leigh and Noble 1972). 


\section{(a) Sclerophyll forest formation (River Red Gum forest)}

The Eucalyptus camaldulensis (River Red Gum) alliance occurs within this formation, although $E$. camaldulensis also occurs as a savannah woodland, the structure being determined principally by soil moisture status. This alliance is restricted in locality to the Murray River and its principal tributaries. It generally occurs as unispecific stands of trees up to $55 \mathrm{~m}$ in height in the better watered areas. In the drier and usually higher habitats the proportion of Eucalyptus largiflorens (Black Box) increases.

Beneath the trees there are grasses, sedges, rushes and other herbs which grow luxuriantly in good seasons and following the recession of flood waters. Many aquatic and semi-aquatic plants occur in permanent and semi-permanent, still or slow-moving waters.

Most of the area occupied by $E$. camaldulensis forest is administered by the New South Wales Forestry Commission. All large trees with millable timber have been felled and unfortunately no stands of trees in their original condition remain. Parts of the forest areas are grazed, mainly by cattle, for certain periods on an agistment basis. The construction of various weirs has enabled flooding to be controlled to some degree and some management has been possible. No evidence is available as to the extent to which these grazing and water management practices have altered the diversity of the species, productivity and overall composition of the understorey flora, but it is believed to have been slight.

Whilst the authors have made frequent visits into the forest areas south of Deniliquin, this area is difficult to cover thoroughly. Similarly, much of the lowlying country along the Murrumbidgee and Lachlan River's warrants closer examination.

\section{(b) Woodland formation}

Three subformations occur under this classification, namely tall woodland (Eucalyptus microcarpa (Grey Box) alliance), shrub woodland (Acacia pendula (Boree)-Atriplex nummularia (Oldman Saltbush) alliance) and savannah woodland (E. camaldulensis (River Red Gum) and E. largiflorens (Black Box) alliances). Mention has already been made of the E. camaldulensis alliances and they need not be discussed further. At the present time only small areas of the other original climax communities remain and these are usually in a degenerate form. The trees have been cleared to provide farming land, timber and/or drought feed. The edible shrubs have mostly long since been grazed out.

The most widespread subformation is tall woodland represented by the $E$. microcarpa (Grey Box) alliance and its three associations. The classification of the Grey Boxes has been somewhat confused, particularly in relation to Eucalyptus woollsiana and E. microcarpa. Moore $(1953 a, 1953 b)$ classified the Grey Box woodlands of the Riverine Plain as being of the $E$. woollsiana alliance. More recently the specific epithet of microcarpa has been applied to the predominant species of Grey Box on the Plain. Although E. microcarpa was regarded by Pryor and Johnson (1971) as a subspecies of E. woollsiana, L.A.S. Johnson (pers. comm.) now concludes that the name "woollsiana" applies to populations intermediate between $E$. pillagaensis and $E$. microcarpa, and does not favour its use. In the area concerned in the present paper the taxon occurring is $E$. microcarpa according to Johnson's present arrangement.

The E. microcarpa association occurred on the medium- and heavy-textured soils, this species being the sole tree dominant. The original understorey was probably well-developed and dominated by the grasses Themeda australis, Poa labillardieri and Stipa aristiglumis (Moore 1953b). However, these grasses are now almost totally absent and the understorey is dominated by Danthonia spp., Stipa variabilis and Maireana pentagona. Many naturalized annuals may be found 
growing in the cooler months. In moist summers Chloris truncata and Sporobolus caroli are common. The well-drained sites on medium- to light-textured soils were originally occupied by the Eucalyptus melliodora (Yellow Box)-Callitris columellaris: (White Cypress Pine) association, whilst on lighter soils the $E$. microcarpa-C. columellaris association occurred. It is believed that in both of these associations. the original herbaceous stratum was poorly developed and dominated by Themeda australis, Poa labillardieri, Stipa aristiglumis and Enneapogon nigricans (Moore 1953b). However, under normal conditions at the present time neither $T$. australis nor $\boldsymbol{P}$. labillardieri are found but $\boldsymbol{S}$. aristiglumis may still be found in lightly grazed or protected situations. Present-day dominants are Danthonia spp. and $S$. variabilis. In the cooler months the understorey cover is usually dominated by annuals.

As mentioned above, only a very small proportion of the area remains in nearpristine climax condition. Large areas have at times been cropped, fertilized and resown to improved pastures. Many useful species, as well as many weeds, have become naturalized as a result of these practices. The area, which is relatively densely settled and easily accessible, has been well-covered from a botanical viewpoint by Moore $(1953 a, 1953 b)$ as well as the present authors, although new plants (particularly weedy species) occasionally come to light.

The Acacia pendula-Atriplex nummularia alliance is the second most widespread of the woodland alliances but today no stands remain with their original structure. From observations of a few isolated areas remaining it has been assumed (Moore $1953 a$ ) that the community was an open woodland with trees up to $9 \mathrm{~m}$ high and a well-developed but probably discontinuous shrub stratum. On the red-brown soils. Acacia pendula was the dominant species with a shrub stratum of Atriplex nummularia, while on the grey and brown elays the dominant species was Atriplex nummularia with scattered Acacia pendula. Other associated shrubs included Rhagodia spinescens, Enchylaena tomentosa and Maireana aphylla. The herbaceous stratum was probably not well-developed. Naturalized species, particularly annuals, are now common.

The Eucalyptus largiflorens alliance occupies a relatively small total area, confined to low-lying areas of heavy grey soil with poor drainage and subject to infrequent flooding. This alliance is a typical savannah with an open canopy allowing the development of a continuous cover of herbaceous plants, although in some locations a dense shrub stratum of Atriplex nummularia occurred. The botanical changes which have followed clearing and/or grazing, are somewhat similar to those described for the $E$. microcarpa alliance. The $E$. largiflorens alliance has probably been well-examined botanically.

\section{(c) Shrub steppe formation}

The shrub steppe formation includes all treeless areas dominated by low-growing perennial bushes. This formation includes two subformations: the saltbush steppe, represented by the Atriplex vesicaria (Bladder Saltbush) alliance, and the bluebush steppe represented by the Maireana pyramidata (Black Bluebush) alliance.

The $A$. vesicaria alliance is the most widespread of those found on the Riverine Plain. Within this alliance are four associations (see Table 1) of which the $A$. vesicaria association is the most common and widespread. Within the $A$. vesicaria association the $A$. vesicaria-Maireana aphylla (Cotton Bush) association occurs in slightly depressed areas on very heavy soils. $A$. vesicaria and $M$. aphylla generally grow as individual plants or as three or four plants together to a height and diameter of 40-60 cm, although ungrazed plants may reach a diameter of $1.5 \mathrm{~m}$. The bushes form an open community, the clumps being separated by distances equal to, or greater than, the diameter of the bushes. In some areas the soil between the bushes remains almost bare throughout the year, even under good seasonal conditions, whereas in others it supports numerous species of annual, and to a lesser degree, 
perennial grasses and herbs. In northern and western districts the suceulent herb Disphyma clavellatum (Pig-face) is often a prominent constituent, and may become the dominant ground flora species.

An extensive proportion of this alliance remains in a superficially near-pristine condition. The major change has been the great increase in naturalized herbaceous species, particularly species of the genus Medicago. There are no areas yet to be colonized by naturalized species. Over the remainder of the area formerly occupied by this alliance major vegetation changes have occurred as a result of grazing, Atriplex vesicaria in particular being susceptible to overgrazing. With a reduction in $A$. vesicaria and Maireana aphylla there has been a marked increase in annual and perennial grasses and herbs as well as unpalatable weed shrubs, notably Bassia spp. and Nitraria billardieri (Dillon or Nitre Bush).

The remaining two associations within this alliance occur over relatively small areas. The Atriplex nummularia association is confined to the better watered drainage lines and is considered as an extension of the Acacia pendula-Atriplex nummularia alliance. Individual bushes are usually one to two metres high but may reach a height of three metres.

The Muehlenbeckia cunninghamii (Lignum) association is confined to permanent or semi-permanent swamps, usually in association with Eragrostis australasica (Cane Grass).

Much of our experimental work has been carried out over a number of years in various associations within the Atriplex vesicaria alliance. Because of the accessibility of the area and the open structure of the vegetation, individual plants are relatively easily seen and this alliance has probably been well-explored. However, it is worth mentioning that we have been amazed by the wealth of species which occurs in years of exceptionally high rainfall. In years of moderate to low rainfall these species have not appeared and it must be concluded that they have seeds characterized by long viability.

The second subformation within this formation is the bluebush steppe. This is represented by the Maireana pyramidata alliance, which includes the $M$. pyramidata association. On the Riverine Plain this association is found only in small areas on red-brown sandy soils in which limestone nodules occur at a depth of one to two metres below the surface. The bushes rarely exceed one to two metres in height and in undamaged areas are separated by distances equal to or slightly less than the diameter of the bushes. Between the bushes herbaceous plants, including perennial grasses, may be abundant in favourable seasons. Naturalized herbaceous species are common. In most areas where $M$. pyramidata is growing, there has been extensive damage to the bushes and to the ground flora, soil erosion being common. This alliance covers only small areas, and has been thoroughly examined.

\section{REFERENCES}

Beadle, N.C.W. (1948)_-“The Vegetation and Pastures of Western New South Wales". (Govt. Printer: Sydney).

Butler, B.E. (1950)-Theory of prior streams as a causal factor of soil occurrence in the Riverine Plain of south-eastern Australia. Austral. J. Agric. Res. 1: $231-52$.

Leigh, J.H., and Mulham, W.E. (1965)_-_"Pastoral Plants of the Riverine Plain". (Jacaranda Press: Melbourne).

Leigh, J.H., and Noble, J.C. (1972) - "Riverine Plain of New South Wales. Its Pastoral and Irrigation Development". (Canberra, Div. Pl. Ind. C.S.I.R.O. Aust.). 
Moore, C.W.E. (1953a)-The vegetation of the south-eastern Riverina, New South Wales. 1. The climax communities. Austral, J. Bot. 1: 485-547.

Moore, C.W.E. (1953b)-The vegetation of the south-eastern Riverina, New South Wales. 2. The disclimax communities. Austral. J. Bot. 1: 548-67.

Pels, S. (1964)-Quaternary sedimentation by prior streams on the Riverine Plain, south-west of Griffith, N.S.W. J. Proc, R. Soc, N.S.W. 97: 107-15.

Pryor, L.D., and Johnson, L.A.S. (1971)-“A Classification of the Eucalypts". (The Australian National University: Canberra).

Stannard, M.E. (1963)_Erosion survey of the Central East-Darling region. Part 3 -Vegetation. J. Soil Conserv. Serv. N.S.W. 19: 17-28.

Turner, F. (1904)-The botany of south-western New South Wales. Proc. Linn. Soc. N.S.W. 29: 132-81.

Warren Wilson, J., and Leigh, J.H. (1964)-Vegetation patterns on an unusual gilgai soil in New South Wales. J. Ecol. 52: 379-89.

Williams, O.B. (1955)-Studies in the ecology of the Riverine Plain. 1. The gilgai microrelief and associated flora. Austral. J. Bot. 3: 99-112.

Williams, O.B. (1956)—Studies in the ecology of the Riverine Plain. II. Plant-soil relationships in three semi-arid grasslands. Austral. J. Agric. Res. 7: 127-39.

Williams, O.B. (1961) - Studies in the ecology of the Riverine Plain. III. Phenology of a Danthonia caespitosa Gaudich. grassland. Austral. J. Agric. Res. 12: 247-59.

Williams, O.B. (1966)_Population changes of the perennial tussock-grass Danthonia caespitosa Gaudich. in a semi-arid environment between the years 1949 and 1965. Proc. Ecol. Soc. Aust. 1: 111-17.

Williams, O.B. (1968a)-Studies in the ecology of the Riverine Plain. IV. Basal area and density changes of Danthonia caespitosa Gaudich. in a natural pasture grazed by sheep. Austral. J. Bot. 16: 565-78.

Williams, O.B. (1968b)-That uneasy state between animal and plant in the manipulated situation. Proc. Ecol. Soc. Aust. 3: 167-74. 


\section{PTERIDOPHYTA}

DENNSTAEDTIACEAE

Pteridium Gled. ex Scop.

P. esculentum (Forst. f.) Cockayne: "Austral Bracken". Only known occurrence on bank of Murray River, east of Mathoura. Apparently not eaten there, elsewhere reported to cause internal cancers in livestock. Den.

\section{MARSILEACEAE \\ Marsilea L.}

M. angustifolia R. Br.: "Narrow-leaved Nardoo". Widespread but uncommon, occurring on edges of swamps and in low-lying areas subject to occasional inundation. Den.

M. drummondii A. Br.: "Nardoo". Very common throughout in damp situations. Eaten at times, suspected of being poisonous to stock. Den.

\section{AZOLLACEAE}

Azolla Lam.

A. fliculoides Lam. var. rubra (R. Br.) Strasburger: "Red Azolla". Common and widespread on surface of still waters such as swamps, backwaters and lagoons. Den.

\section{GYMNOSPERMAE}

\section{CUPRESSACEAE}

Callitris Vent.

C. columellaris F. Muell. inland form: "White Cypress Pine". Den.

C. preissii Miq. ssp. murrayensis J. Garden: “Murray Cypress Pine”. Den.

Intermediate forms between these two species are found in the southern part of the area and further west, and there appears to have been considerable hybridization in intermediate habitats. In general, C. preissii spp. murrayensis is found in the Murray River country on old sandhills whereas $C$. columellaris (inland form) is the common species in the Narrandera area and away from the river country. (L. Johnson, pers. comm.). These species originally occurred in dense stands which have been reduced because of utilization of timber for building and fencing and because of clearing for cropping.

\section{ANGIOSPERMAE MONOCOTYLEDONEAE TYPHACEAE \\ Typha $\mathrm{L}$.}

T. orientalis Presl: "Cumbungi". Infests extensive areas of creek and river country, also prevalent in shallow waterways, tanks, drains, and swamps. In the early stages of growth it is eaten to some extent by cattle. Den.

T. domingensis Pers.: "Cumbungi". Similar distribution and habitats to those of T. orientalis. NSW. 
POTAMOGETONACEAE

Potamogeton L.

P. ochreatus Raoul: Collected at Jerilderie, 1951, probably overlooked elsewhere. NSW.

P. tricarinatus F. Muell. et A. Benn.: "Floating Pondweed". Common and widespread, growing partly submerged in swamps and streams. Den.

\section{JUNCAGINACEAE}

Triglochin L.

T. procera R. Br.: "Water Ribbons". Common in swamps, dams and backwaters of streams throughout the area. Den.

T. calcitrapa Hook.: Only known occurrence in an Atriplex vesicaria pasture near Wanganella, but may have been overlooked in other areas because of its small size. Den.

T. turrifera Ewart: Collected at "Zara", Wanganella, 1917. NSW.

\section{ALISMATACEAE}

Damasonium Juss.

D. minus (R. Br.) Buchen.: "Starfruit". Fairly common in swamps and along the margins of backwaters. Den.

\section{HYDROCHARITACEAE}

Elodea Michx.

* E. canadensis Michx.: "Elodea". A widespread aquatic weed, common in streams and irrigation channels. Den.

\section{Ottelia Pers.}

O. ovalifolia (R. Br.) L.C. Rich.: "Swamp Lily". Common in streams, backwaters and swamps. Den.

\section{POACEAE ( = GRAMINEAE) \\ Agropyron Gaertn.}

A. scabrum (R. Br.) Beauv.: "Common Wheat Grass". Fairly widespread though relatively uncommon, occurring mainly on river flats and extending into lightly grazed pastures. Useful forage when young. Den.

\section{Agrostis L.}

A. avenacea Gmel.: "Blown Grass". Very common in moist situations throughout the area. Grazed when young, unpalatable when mature. Den. The similar A. aemula $\mathrm{R}$. Br. may also occur in the area but no specimen was seen except "A. avenacea verging towards aemula", from Jerilderie district, 1880 . NSW.

\section{Aira L.}

* A. cupaniana Guss.: "Silvery Hair Grass". Common in southern and eastern districts. Of no economic importance. Den. 


\section{Alopecurus L.}

* A. geniculatus L.: "Marsh Foxtail". In depressions and moist situations throughout the area; very common. Grazed when young. Den.

\section{Amphibromus Nees}

A. neesii Steud.: "Swamp Wallaby Grass". Common in moist situations; widespread. Useful cattle forage. Den.

\section{Aristida L.}

A. armata Henr.: Fairly common in forest areas bordering Murray River. Den.

A. behriana F. Muell.: "Brush Wire Grass". Widespread throughout, usually on soils of light texture. Of some forage value, though awned seeds can be troublesome to stock. Den.

A. jerichoensis Domin var. subspinulifera Henr.: Occurs on sandhills, mainly in southern and eastern districts. Uncommon. Den.

Avena L.

* A. fatua L.: "Wild Oat". Very common and widespread. Grazed readily in early stages of growth. Den.

\section{Bothriochloa Kuntze}

B. macra (Steud.) S.T. Blake: "Red-leg Grass". Widespread in southern districts, usually occurring in localized patches in slight depressions in open woodlands and grasslands. Not highly regarded but grazed to some degree in its early stages. Den.

\section{Briza L.}

* B. minor L.: "Shivery Grass". Not widely distributed but common in some south" ern and eastern districts. Of little forage value. Den.

\section{Bromus L.}

* B. alopecuroides Poir.: "Curly Brome". Fairly common in localized areas on light soils. Of little economic importance. Den.

B. arenarius Labill.: "Sand Brome". Common, particularly on light soils. Of some forage value before maturity. Den.

* $B$. diandrus Roth: "Great Brome”. Of limited occurrence on light soils; a weed with troublesome awned seeds. Den.

* B. molliformis Lloyd: "Soft Brome". Widespread and fairly common, particularly on light soils; of some value as forage but only when young. Den.

* B. mollis L.: "Soft Brome". Widespread and very common; utilized when young but becomes unpalatable with maturity. Den.

* B. rubens L.: "Red Brome". Widespread and very common on all soils; provides some forage in its early stage of growth but becomes rank and unpalatable. Den.

* B. unioloides Kunth: "Prairie Grass". A widespread and common weed; occasionally a useful forage plant but rarely of economic importance. Den.

Cenchrus L.

* C. incertus M.A. Curtis: Collected from near Barham. NSW.

* C. longispinus (Hack.) Fern.: "Spiny Burr Grass". A weed restricted to localized areas on sandy soils: the burrs are particularly spiny and troublesome. Den. 


\section{Chloris Swartz}

C. acicularis Lindl.: "Curly Windmill Grass". Widespread and common on a wide range of soils. A valuable perennial grass which responds well to summer rain. Den.

* C. gayana Kunth: "Rhodes Grass". Used in irrigated pastures and occasionally spontaneous in moist situations. A useful species. Den.

C. truncata R. Br.: "Windmill Grass". Widespread and very common on all soils; a valuable summer growing grass. Den.

\section{Cymbopogon Spreng.}

C. obtectus S.T. Blake: "Silky-heads". A rare species; only known occurrence in Tocumwal cemetery. Den.

Cynodon L.C. Rich.

* C. dactylon (L.) Pers.: "Couch". Widespread and very common in moist situations on all types of soils; provides useful forage in summer. Den.

\section{Dactyloctenium Willd.}

D. radulans (R. Br.) Beauv.: "Button Grass". Widespread and fairly common, usually on light soils. Short-lived, grazed at most stages of growth. Den.

\section{Danthonia DC.}

D. caespitosa Gaudich.: "White-top" or "Ringed Wallaby Grass". Widespread; dominant pasture species in grasslands and open woodlands on clay soils in southern and eastern districts, co-dominant with Stipa variabilis on clay loam soils, less frequent in saltbush plains and forest areas. A valuable palatable perennial grass which will withstand heavy grazing. Intergrades between this species and $D$. setacea are also common and widespread. Den.

D. duttoniana A.B. Cashmore: "Brown-backed Wallaby Grass". Fairly common in moist situations, particularly in southern districts; a rather coarse species of limited forage value. Den.

D. setacea R. Br.: "Small-flowered Wallaby Grass". Common, particularly in southern districts; a useful forage species. Intergrades of this species and D. caespitosa are common. Den.

\section{Deyeuxia Clar. ex Beauv.}

D. quadriseta (Labill.) Benth.: "Reed Bent Grass". Known only from forest area south of Deniliquin, where locally common. Den.

\section{Dichelachne Endl.}

D. sciurea (R. Br.) Hook. f.: "Short-haired Plume Grass". Tocumwal cemetery is only known occurrence. Den.

\section{Digitaria Haller}

D. ammophila (Benth.) Hughes: "Silky Umbrella Grass". Widespread but of somewhat sparse occurrence; usually grows on light soils. Drought-resistant, grazed at times. Den.

D. brownii (Roem. et Schult.) Hughes: "Cotton Grass". Recorded from Hay, 1913. NSW. 
D. coenicola (F. Muell.) Hughes: "Finger Panic Grass". Uncommon, usually restricted to light soils; grazed but of unknown forage value. Den.

D. divaricatissima ( $\mathrm{R}$. Br.) Hughes: "Umbrella Grass". Widespread on light soils but rather uncommon: grazed only in occasional years. Den.

* D. sanguinalis (L.) Scop.: "Summer Grass". Widespread and common weed of gardens and irrigation areas. Den.

\section{Diplachne Beauv.}

D. fusca (L.) Beauv.: "Brown Beetle Grass". Common in depressions on heavy soils, in roadside drains, swamps and lagoons; moderately palatable and considered good cattle feed. Den.

\section{Echinochloa Beauv.}

* E. colonum (L.) Link: Den.

* E. crusgalli (L.) Beauv.: Den.

* E. microstachya (Wieg.) Rydb.: Den.

* E. oryzoides (Ard.) Fritsch: Den.

"Barnyard Grasses". Widespread and troublesome summer weeds of crops (particularly rice) and gardens-rare in natural pastures. Palatable, but in most situations in which they occur they are not desirable plants.

\section{Ehrharta Thunb.}

* E. calycina Sm.: "Perennial Veldt Grass". Uncommon; confined to localized areas on sandy soils. Den.

* E. longiflora Sm.: "Annual Veldt Grass". Rare; occasional occurrences on river flats. Den.

\section{Enneapogon Desv. ex Beauv.}

E. avenaceus (Lindl.) C.E. Hubbard: "Bottle-washers". Recorded from Mossgiel and "Zara", Wanganella. Possibly widespread but not collected elsewhere because of its similarity to $E$. nigricans. Readily grazed. NSW.

E. nigricans (R. Br.) Beauv.: "Nigger-heads". Widespread and common on sandy soils. Readily grazed. Den.

E. polyphyllus (Domin) N.T. Burbidge: Recorded from Jerilderie, 1880. NSW.

\section{Eragrostis Beauv.}

E. australasica (Steud.) C.E. Hubbard: "Cane Grass". Widespread and common in low-lying areas. A coarse species which is rarely grazed. Den.

E. brownii (Kunth) Nees ex Steud.: "Brown's Love Grass". Uncommon; rarely occurring in sufficient quantity to be considered useful. Den.

*E. cilianensis (All.) Link ex Lut.: "Stink Grass". Very common and widespread on light soils; a summer weed of fallows and irrigated pastures. Grazed only when young. Den.

* E. curvula (Schrad.) Nees: "African Love Grass". Uncommon except in localized areas on sand-hills in southern districts. Unpalatable, although it may be grazed by hungry stock. Den. 
E. dielsii Pilger: "Mallee Love Grass". Generally uncommon except on sandy soils in western areas. A relatively palatable summer-growing forage plant. Den.

E. elongata (Willd.) J.F. Jacq.: “Clustered Love Grass”. Widespread on sandy soils, generally uncommon. Palatable. Den.

E. eriopoda Benth.: "Woollybutt Grass". Uncommon, occurring in northern and western areas, mainly on light soils. Palatable. Den.

E. lacunaria F. Muell. ex Benth.: "Purple Love Grass". Widespread, though rather uncommon, generally found on light soils. Palatable. Den.

E. parviflora (R. Br.) Trin.: "Weeping Love Grass". Widespread and common, usually in moist situations; a weed in irrigation areas. Fairly palatable. Den.

* E. poaeoides Beauv.: "Smaller Stink Grass". Only known occurrence on loam soil between Deniliquin and Conargo. Den.

E. setifolia Nees: "Neverfail Grass". Widespread and fairly common, particularly in northern districts. A highly regarded palatable species. Den.

\section{Eriochloa Kunth}

E. crebra S.T. Blake: Common on clay soil in western districts. Possibly occurs elsewhere but it may be overlooked because of its similarity to E. pseudoacrotricha. Den.

E. pseudoacrotricha (Stapf ex Thell.) J.M. Black: "Early Spring Grass". Widespread and common in moist situations. A readily-eaten summer species. Den.

\section{Eulalia Kunth}

E. fulva (R. Br.) Kuntze: "Silky Browntop". Widespread but of somewhat sparse occurrence; usually found in moist situations on loam soils. Very palatable. Den.

Glyceria R. Br.

*G. maxima (Hartm.) Holmb.: "Water Meadow Grass". Collected from Colligen Creek, near Stevens Weir; only known occurrence. Den.

Holcus L.

* H. lanatus L.: "Yorkshire Fog". A weed of irrigated pastures and surrounds. Den.

\section{Hordeum L.}

* H. leporinum Link: "Barley Grass". Widespread and very common, particularly on light soils. Grazed readily when young, shunned when mature and dry. Den.

* H. marinum Huds.: "Sea Barley Grass". Widespread, common in damp or saline situations. Grazed only when young. Den.

Iseilema Anderss.

I. membranaceum (Lindl.) Domin: "Flinders Grass". Collected near Wanganella, also recorded in the Hay district, but never common. Den.

G 30537-2 I 
Koeleria Pers.

*K. phleoides (Vill.) Pers.: “Annual Catstail”. Widespread but of sparse occurrence. Palatable. Den.

\section{Lamarckia Moench}

L. aurea (L.) Moench: "Golden-top". Widespread and common on light soils. Palatable. Den.

\section{Leptochloa Beauv.}

L. digitata (R. Br.) Domin: "Umbrella Cane Grass". Appears to be widespread although rare, usually occurring in low-lying areas. Den.

\section{Lolium L.}

*L. perenne L.: "Perennial Ryegrass". Used extensively in irrigated pastures and lawns from where it has occasionally spread into moist situations. Den.

*L. rigidum Gaudin: "Wimmera Ryegrass". A common constituent of irrigated pastures and spontaneous in many dryland areas. Very palatable winterspring forage. Den.

\section{Oryzopsis Michx.}

*O. miliacea (L.) Aschers et Schweinf.: "Rice Millet". Rare; occasionally found in the vicinity of old homesteads and settlements. Den.

\section{Panicum L.}

P. decompositum R. Br.: "Native Millet". Widely distributed and fairly common in moist situations. Palatable. Den.

P. effusum R. Br.: "Hairy Panic". Widespread; fairly common in moist sitvations. Fairly palatable although suspected of poisoning sheep. Den.

$P$. prolutum F. Muell.: "Rigid Panic". Widespread and relatively common. Palatable. Den.

P. whitei J.M. Black: "Pepper Grass". Widespread but of rather sparse occurrence; usually found in drainage lines and depressions. Palatable, especially when young. Den.

\section{Parapholis Hubbard}

*P. incurva (L.) Hubbard: "Curly Ryegrass". Widespread and common on clay soils; tolerant of damp and saline conditions. Palatable. Den.

\section{Paspalidium Stapf}

P. constrictum (Domin) Hubbard: Widely distributed but of somewhat sparse occurrence. Palatable. Previous local references to this plant have been as $P$. gracile (R. Br.) Hughes. NSW.

P. jubiflorum (Trin.) Hughes: "Warrego Summer Grass". Common on river banks and river flats on a wide variety of soils. Palatable. Den.

\section{Paspalum L.}

*P. dilatatum Poir: "Paspalum". Widely used in irrigation pastures from where it has spread into moist situations. Den. 
P. paspalodes (Michx.) Scribn. (= Paspalum distichum L.): "Water Couch". Widespread and common in shallow water of streams and swamps. Palatable. Den.

Pennisetum L.C. Rich. ex Pers.

*P. villosum R. Br.: "Long-Styled Feather Grass". Roadside species around Deniliquin and other areas of habitation. Den.

\section{Pentaschistis Stapf}

*P. airoides (Nees) Stapf: “False Hair Grass". Observed only near Narrandera, where common on loam soil. Den.

\section{Phalaris L.}

*P. aquatica L.: "Phalaris". Used extensively in irrigated pastures, from where it has spread into adjacent moist situations. Den.

*P. minor Retz.: "Lesser Canary Grass". Fairly widespread but common only in localized areas. Moderately palatable when young. Den.

*P. paradoxa L.: "Paradoxa Grass". Widely distributed and very common in localized areas on heavy soils. Palatable when young. Den.

Phragmites Adans.

P. australis (Cav.) Trin. ex Steud.: "Common Reed". Widespread and common, bordering streams throughout the area. Den.

\section{Poa L.}

*P. annua L.: "Annual Poa". "Winter Grass". Very common weed in areas of habitation. Den.

*P. bulbosa L.: "Bulbous Poa". Only known occurrence near Narrandera where it was common on loam soil. Den.

P. fordeana F. Muell.: "Sweet Swamp Grass". Widespread, common in localized areas, particularly in the Booligal district. Den.

$P$. labillardieri Steud.: "Tussock Grass". Common but restricted to areas bordering permanent streams and subject to periodic flooding. Palatable only when young. Den.

*P. pratensis L.: "Kentucky Blue Grass". River flat, Deniliquin. Probably spread from garden rubbish as it is not found in natural pasture elsewhere in area. Den.

$P$. sieberana Spreng.: "Tussock Grass". Only known occurrence on sandy soil in forest area near Mathoura. Den.

\section{Polypogon Desf.}

*P. monspeliensis (L.) Desf.: "Annual Beard Grass". Widely distributed and common in damp, often saline situations. Apparently unpalatable. Den.

\section{Pseudoraphis W. Griffith}

P. spinescens (R. Br.) J. Vickery: "Spiny Mud Grass". Widespread and fairly common; growing in mud and shallow water in streams and swamps. Den. 
Puccinellia Parl.

P. stricta (Hook, f.) C. Blom: "Marsh Grass". Recorded for flooded clay plains near Moulamein and from near Oxley. Den.

Schismus Beauv.

*S. barbatus (L.) Thell.: “Arabian Grass". Widespread and common, mainly on sandy soils. Moderately palatable. Den.

Setaria Beauv.

*S. verticillata (L.) Beauv.: "Whorled Pigeon Grass", "Rough Bristle Grass". Widespread; common in moist cultivated areas and gardens. Palatable, but regarded as a weed. Den.

\section{Sporobolus R. Br.}

S. caroli Mez: "Fairy Grass". Widespread and common in a wide variety of habitats. Very palatable; a valuable summer forage plant. Den.

S. mitchellii (Trin.) Hubbard ex S.T. Blake: "Rat's-tail Couch". Widespread; common in localized areas along water-courses. Den.

\section{Stipa L.}

S. aristiglumis F. Muell.: "Plains Grass". Widespread and fairly common in a wide range of habitats. Moderately palatable. Den.

S. blackii Hubbard: One collection, from near Berrigan. NSW.

$S$. drummondii Steud.: Identification uncertain. Recorded from Millewa Forest, near Mathoura. Den.

S. elegantissima Labill.: “Feather Spear Grass". Widespread but of sparse occurrence, usually growing in protected situations. Presumably very palatable. Den.

S. nitida Summerhayes et Hubbard: Recorded from Jerilderie in 1880 . Possibly included under $S$. variabilis in more recent years. NSW.

S. platychaeta Hughes: One record, from Hay, 1885. NSW.

S. variabilis Hughes: "Variable Spear Grass". Widespread and very common, particularly on light soils. A useful forage species, although seeds are troublesome to stock, penetrating the eyes, feet and skins of young animals, sometimes to the point of causing death. The value of meat and hides containing large quantities of seeds is decreased. Den.

\section{Themeda Forsk.}

T. australis (R. Br.) Stapf.: “Kangaroo Grass”. Widespread; originally common, now confined to localized protected areas. Very palatable. Den.

\section{Tragus Haller}

T. australianus S.T. Blake: "Small Burr Grass". Widespread and locally common on light soils. Palatable but short-lived. Den.

Tripogon Roem. et Schult.

T. loliformis (F. Muell.) Hubbard: "Five-minute Grass". Widespread and fairly common on light soils. Palatable. Den. 
Triraphis R. Br.

T. mollis R. Br.: "Needle Grass". Uncommon; from "Zara", Wanganella (1913) and more recently from "Willurah" between Conargo and Hay. Den.

Trisetum Pers.

*T. pumilum (Desf.) Kunth: "Tiny Bristle Grass". Common on loam soil on western boundary of Riverine Plain; not collected elsewhere. Den.

Vulpia K.C. Gmel.

*V. myuros (L.) K.C. Gmel.: “Rat's-tail Fescue". Widespread and common on all soils. Fairly palatable in the early growth stage, ignored when mature. Den.

\section{CYPERACEAE}

Carex L.

C. appressa R. Br.: “Tall Sedge”. Widespread on stream banks, swamps and damp places. Den.

C. inversa $\mathrm{R}$. Br. inland form: "Knob Sedge". Widespread and common in moist situations. Fairly palatable. Den.

\section{Cyperus L.}

C. bifax C.B. Clarke: "Downs Nut-grass". One collection from shallow water at "Ulonga", near One Tree, $40 \mathrm{~km}$ north of Hay. Den.

C. concinnus R. Br.: Recorded from swamp at "Ulonga", near One Tree. Dis tribution unknown. Den.

C. difformis L.: "Dirty Dora". Common in swamps and in rice-growing areas. Den.

*C. eragrostis Lam.: "Umbrella Sedge". Widespread; a common weed of river banks, channels, drains, etc. Den.

C. exaltatus Retz.: Widespread and common on water's-edge along rivers and creeks. Den.

C. gymnocaulos Steud.: Widespread; common near water, usually on sandy soil. Den.

C. pygmaeus Rottb. Collected near Lachlan River at Oxley. NSW.

C. victoriensis Clarke: Recorded from river-flat near Deniliquin. Widespread in similar situations. Den.

\section{Eleocharis R. Br.}

E. acuta R. Br.: "Common Spike Rush". Widespread; common in low-lying areas and along the margins of rivers etc. Unpalatable. Den.

E. pallens (Benth.) S.T. Blake: "Pale Spike Rush". Widespread; common in low-lying areas and along the margins of rivers etc. Unpalatable. Den.

E. pusilla R. Br.: "Small Spike Rush". Widespread and common on flat areas along the margins of streams and swamps. Den. 
Fimbristylis Vahl

F. dichotoma (L.) Vahl: "Common Fringe-rush". Collected from near Jerilderie. Den.

F. velata $\mathrm{R}$. Br. One collection from near Moama. NSW.

Lipocarpha $\mathrm{R}$. Br.

L. microcephala (R. Br.) Kunth: One record from Stevens Weir; distribution unknown. Den.

\section{Scirpus L.}

S. inundatus (R. Br.) Poir.: Widespread and common in moist situations. Den.

S. victoriensis Wakefield: Widespread, occurring in damp, low-lying situations near streams in southern districts. Den.

LEMNACEAE

Spirodela Schleid.

S. pusilla (Hegelm.) Hegelm.: a "Duckweed".

Material from the area has been identified under this name but the taxonomy of the group requires further study and it is also possible that other species of Spirodela or Lemna may occur.

\section{JUNCACEAE}

Juncus L.

*J. acutus L.: "Sharp Rush". Collected from sites near Berrigan and near Barham. NSW.

J. amabilis E. Edgar: Found in the Tocumwal area. NSW.

$J$. aridicola L. Johnson (ined.): Common and widespread wherever water lies for any length of time. NSW.

J. bufonius L.: "Toad Rush". Widespread; fairly common in moist situations. Palatable. Den.

J. flavidus L. Johnson (ined.): Collections made from area between Hay and Balranald, probably common elsewhere. NSW.

J. homalocaulis F. Muell.: Recorded from Millewa State Forest, near Mathoura, in which area it was common. Distribution unknown. Den.

J. ingens N.A. Wakefield: "Giant Rush". Found only in low-lying areas adjacent to Murray River. Den.

J. semisolidus L. Johnson (ined.): One collection from south of Mathoura. NSW.

J. subsecundus N.A. Wakefield: Recorded from the Caldwell-Moama district. NSW.

J. usitatus L. Johnson: Common throughout the area, particularly along irrigation channels. NSW.

Some of the species listed have not yet been described but are well-known and will be dealt with in a forthcoming revision (L.A.S. Johnson, pers. comm.). 


\section{LILIACEAE}

Anguillaria $\mathrm{R}$. Br.

A. dioica R. Br.: "Early Nancy". Common in grassland pastures in southern and eastern districts. Palatable. Den.

\section{Arthropodium R. Br.}

A. milleflorum (DC.) Macbride: "Pale Vanilla-lily". Relatively uncommon except in grassland areas of southern and eastern districts. Palatable. Den.

A. minus R. Br.: "Small Vanilla-lily". Relatively uncommon except in southern and eastern grasslands. Palatable. Den.

\section{Asparagus L.}

*A. officinalis L.: "Asparagus". Recorded only from Deniliquin area, where it is found on heavy clay soil. Presumably a garden escape. Den.

\section{Asphodelus L.}

*A. fistulosus L.: "Onion Weed"'. Very common weed on light soils in western areas. Unpalatable. Den.

\section{Bulbinopsis Borzi}

B. bulbosa (R. Br.) Borzi: "Native Leek". Widespread but of sparse occurrence. Palatable; reputedly poisonous when eaten in quantity. Den.

B. semibarbata (R. Br.) Borzi: “Leek Lily". Widespread, locally very common, especially on light soils. Palatable. Den.

Dianella Lam. ex Juss.

D. laevis R. Br.: "Pale Flax-lily". Sparsely distributed throughout protected areas of forest and woodland in southern districts. Apparently palatable. Den.

\section{Dichopogon Kunth}

D. fimbriatus (R. Br.) Macbride: "Nodding Chocolate Lily". Sparse occurence in woodlands and grasslands in southern districts. Palatable. Den.

\section{Thysanotus R. Br.}

T. patersonii R. Br.: “Twining Fringe-lily". Restricted to protected areas in eastern districts. Den.

\section{Tricoryne R. Br.}

T. elatior R. Br.: "Yellow Rush-lily". Recorded only from sandy soil in Millewa State Forest, near Mathoura, where locally common. Den.

\section{XANTHORRHOEACEAE}

Lomandra Labill.

L. effusa (Lindl.) Ewart: "Scented Mat-rush". Locally common on sandy-loam soils in southern districts. Unpalatable. Den.

L. leucocephala (R. Br.) Ewart ssp. robusta A. Lee: "Woolly Mat-rush". Recorded only from Tocumwal cemetery; sandy soil. Den. 
L. multiflora (R. Br.) Britten: "Many-flowered Mat-rush". Recorded only from Tocumwal cemetery; sandy soil. Den.

\section{AMARYLLIDACEAE}

Calostemma R. Br.

C. purpureum R. Br.: "Wilcannia Lily". Generally uncommon, occurring in localized patches in low-lying areas in woodlands and grasslands. Apparently palatable. Included under C. purpureum is C. luteum Sims. Den.

\section{HYPOXIDACEAE}

\section{Hypoxis $\mathrm{L}$.}

H. pusilla Hook. f.: "Tiny Star". Widespread and common in grasslands on loam and clay soils. Palatable. Den.

\section{IRIDACEAE}

Romulea Maratti

${ }^{*} R$. sp. (probably $R$. minutiflora Klatt): "Small-flowered Onion Grass". Very common in heavily grazed pastures adjacent to areas of habitation, generally on clays and clay-loams; also a garden weed. Unpalatable. Den.

\section{ORCHIDACEAE}

Caladenia R. Br.

C. dilatata R. Br. var. dilatata: "Green-comb Spider Orchid". One record only, from "Zara," Wanganella, 1917. NSW.

Diuris $\mathrm{Sm}$.

D. pedunculata R. Br.: "Golden Moths". Extremely rare, one collection from sandy soil near Tocumwal. Den.

Microtis $\mathrm{R}$. Br.

M. unifolia (Forst. f.) Reichenb.: "Common Onion-orchid". Of sparse occurrence, though locally common in wet situations in forest areas along Murray River. Den.

\section{DICOTYLEDONEAE \\ CASUARINACEAE \\ Casuarina Adans.}

C. cristata Miq. ssp. pauper (F. Muell. ex Miq.) L. Johnson: "Belah". Recorded from Deniliquin and Moama; extremely rare in Riverine Plain although it is common in adjacent country to north and west. A low grade though useful drought forage where it is available in quantity. NSW.

C. luehmannii R.T. Baker: "Bull Oak". Widespread on light soils. Coarse and unpalatable foliage, low-grade timber. Den.

\section{CANNABACEAE}

Cannabis $\mathbf{L}$.

*C. sativa L.: "Hemp". One collection from forest area south of Deniliquin. Den. 


\section{URTICACEAE}

\section{Parietaria L.}

P. debilis Forst. f.: "Forest Pellitory". One collection from damp area in Eucalyptus largiflorens woodland, near Conargo. Distribution unknown. Den.

\section{Urtica L.}

*U. urens L.: "Small Nettle". A weed of waste places and cultivated land, more common on light soils. Den.

\section{PROTEACEAE}

Hakea Schrad.

H. leucoptera R. Br.: a "Needlewood". Widespread and common, usually in localized areas on light soil. Foliage unpalatable. Den.

H. tephrosperma R. Br.: a "Needlewood". Apparently of similar distribution and occurrence to $H$. leucoptera. Den.

\section{LORANTHACEAE}

\section{Amyema Tiegh.}

A. linophyllum (Fenzl) Tiegh. ssp. orientale Barlow: "Mistletoe". Recorded from near Mathoura; host tree Casuarina luehmannii. Apparently widespread. Den.

A. miquelii (Lehm. ex Miq.) Tiegh.: "Mistletoe". Widespread and very common on species of Eucalyptus. Den.

A. miraculosum (Miq.) Tiegh. ssp. boormanii (Blakely) Barlow: "Mistletoe". Recorded from near Wanganella; host tree Eremophila longifolia. Widespread. Den.

A. preissii (Miq.) Tiegh.: "Mistletoe". Recorded from near One Tree; host tree Acacia sp. Probably widespread. Den.

A. quandang (Lindl.) Tiegh. var. quandang: "Grey Mistletoe". Widespread and common on Acacia pendula. Den.

\section{Lysiana Tiegh.}

L. exocarpi (Behr ex Schlecht.) Tiegh. ssp. exocarpi: "Mistletoe". Recorded from near Wanganella; host tree Eremophila longifolia. Widespread. Den. Intermediates between this and ssp. diamantinensis (J.M. Black) Barlow occur as well as intermediates between ssp. diamantinensis and ssp. tenuis (Blakely) Barlow. Den.

\section{SANTALACEAE}

Exocarpos Labill.

E. aphyllus R. Br.: "Jointed Cherry". Widespread but uncommon; prefers sandy and clay-loam soils. Den.

E. strictus R. Br.: "Slender Cherry". Sparsely distributed; apparently restricted to forest areas. Den.

\section{Santalum L.}

S. acuminatum (R. Br.) A. DC.: "Quandong". Widespread but now of very sparse occurrence, usually found on loam and sandy-loam soils. Moderately palatable. Den. 
S. lanceolatum R. Br.: "Sandalwood". Widely distributed but rather uncommon; confined to sandy and loam soils. Unpalatable. Den.

\section{POLYGONACEAE}

\section{Acetosa Mill.}

* A. vesicaria (L.) Löve: "Pink Dock", "Bladder Dock". Collected from bank of Mulwala Canal between Barooga and Berrigan. Not known to occur elsewhere. Den.

\section{Acetosella Fourr.}

* A. vulgaris Fourr. sens. lat. (= Rumex acetosella L.): "Sorrel". Common only in localized areas in regions of higher rainfall, usually restricted to light soils. Suspected of being poisonous to stock. Den.

\section{Emex Neck.}

*E. australis Steinh: "Spiny Emex", "Double Gee”. Uncommon, occasional plants on light soil. Unpalatable, with troublesome spiny fruits. Den.

\section{Muehlenbeckia Meisn.}

M. cunninghamii (Meisn.) F. Muell.: "Lignum". Widespread and common throughout, in swampy or intermittently flooded country. Unpalatable, though grazed occasionally. Den.

M. diclina (F. Muell.) Druce: "Slender Lignum". One collection from near "Manfred" southwest of Ivanhoe. NSW.

M. horrida H. Gross: Uncommon; distribution unknown. Two collections, one near Wakool, one near Hay. Den.

\section{Polygonum L.}

*P. arenastrum Bor.: "Wireweed". Collected from area between Maude and Oxley. Probably common elsewhere. NSW.

*P. aviculare L.: "Wireweed". Widespread weed; common, particularly in disturbed areas on light soils. Of low palatability, suspected of causing stock disorders. Den.

$P$. decipiens $\mathrm{R}$. Br.: "Slender Knotweed". Widespread; common around swamps and streams, on soil from which water has receded. Den.

$P$. hydropiper L.: "Waterpepper". Infrequent plants in flooded country along Murray River. Suspected of causing stock disorders; low palatability. Den.

P. lapathifolium L.: "Pale Knotweed". Widespread, common in localized areas along streams and the edges of swamps. Den.

P. plebeium R. Br.: "Small Knotweed". Widespread but habitat apparently restricted to clay soil near water. Den.

P. prostratum R. Br.: "Creeping Knotweed". Fairly widespread, common on river flats, uncommon elsewhere. Palatable. Den. 
Rumex L.

R. bidens R. Br.: Collected from Lake Whymoul, near Barham. NSW.

$R$. brownii Campd. "Swamp Dock". Widespread and common in moist areas Den.

*R. conglomeratus Murr.: “Clustered Dock”. Widespread and fairly common in moist situations. Den.

*R. crispus L.: "Curled Dock". Widespread and very common weed in moist areas. Den.

R. crystallinus Lange: “Shiny Dock". Widespread and common, very prevalent where water has receded in shallow swamps. Den.

R. dumosus A. Cunn. ex Meisn.: "Wiry Dock”. Widespread; occurs as scattered plants in a wide variety of situations. Den.

R. tenax Rech. f.: Widespread and common in damp situations. Den.

\section{CHENOPODIACEAE}

\section{Atriplex L.}

A. angulata Benth.: "Fan Saltbush". Collected along Hay-Balranald road. Not known to occur elsewhere on Plain. Den.

A. conduplicata F. Muell.: From near Booligal, apparently rare. NSW.

A. eardleyae Aellen: Collected from Wanganella and Booligal but not common on the Riverine Plain. Moderately palatable. NSW.

A. holocarpa F. Muell.: "Pop Saltbush”. Widespread north of the Murrumbidgee River. Somewhat similar in appearance to $A$. spongiosa of which it has at times been considered a variety, but distinct. Of low palatability. Den.

A. leptocarpa F. Muell.: "Slender-fruited Saltbush". Widespread and locally common, particularly on loam and clay-loam soils. Palatable and provides useful forage during dry periods. Den.

A. lindleyi Moq.: Widespread and common in all but southern districts, very prevalent in degraded $A$. vesicaria pastures. Apparently unpalatable. Den.

A. nummularia Lindl.: "Oldman Saltbush". Widespread and originally very common-now restricted to protected areas adjacent to homesteads in the south and to areas receiving additional water in the form of run-off in the north and west. Not particularly palatable but provides good forage during drought. Den.

A. pseudocampanulata Aellen: Annual species common throughout, particularly in clay soils along roadsides. Unpalatable. Den.

A. spongiosa F. Muell.: “Pop Saltbush". Distribution and forage value similar to that of $A$. holocarpa. Den.

A. spinibractea R.H. Anderson: Collected from Jerilderie cemetery and near Deniliquin. Den.

A. suberecta Verdoorn: Common in localized areas on a range of soil types. Previously included under $A$. muelleri which is a more northern species. Relatively palatable but rarely occurring in sufficient quantity to be of any great value. Den. 
A. vesicaria Hew. ex Benth.: "Bladder Saltbush". Common, extending over wide areas from Deniliquin north. Whilst not highly palatable it forms a valuable maintenance forage during dry times, provides cover for the more palatable associated grasses and forbs and protects the soil surface from erosion. Den.

\section{Babbagia F. Muell.}

B. acroptera F. Muell. et Tate var. deminuta J.M. Black: "Babbagia". Common on roadsides and in degraded saltbush pastures, mainly north of Hay. Moderately palatable. Den.

\section{Bassia All.}

B. bicornis (Lindl.) F. Muell. var. bicornis: "Goathead Burr". Moderately common, particularly in northern areas, although generally of localized occurrence. Eaten at times but generally regarded as a weed. Den.

B. biflora (R. Br.) F. Muell. var. biflora: Occasional occurrence, more common in northern areas, usually as understorey to larger shrubs such as Atriplex nummularia. Den.

B. birchii (F. Muell.) F. Muell.: "Galvanized Burr". Originally not common on the Riverine Plain, this species has of recent years invaded large areas of light soil in the Hay and Deniliquin districts. A troublesome noxious weed. Den.

B. brachyptera (F. Muell.) R.H. Anderson: Common throughout saltbush country, to which it is apparently restricted. Lacks spines and is palatable to stock. Den.

B. diacantha (Nees) F. Muell.: “Grey Copper Burr”. Very prevalent on light soils around northern and western perimeter of the Riverine Plain, with occasional plants being found throughout the Plain, usually on well drained soils. Fairly palatable despite spiny fruits. Den.

B. divaricata (R. Br.) F. Muell.: "Copper Burr". Common in saltbush country, where it is prevalent in depressions and on self mulching clays. Very spiny, rarely grazed. Den.

B. intricata R.H. Anderson: Common throughout degraded saltbush pastures north and west of Hay. Unpalatable. Den.

B. lanicuspis (F. Muell.) F. Muell.: Uncommon except on small areas of light soil supporting Maireana pyramidata in the north and west. Palatable, with soft spines until maturity. Den.

B. paradoxa (R. Br.) F. Muell. var. paradoxa: Common on light soils along northern and western perimeter of the Riverine Plain, occasionally on clay soils north of Hay. Not readily acceptable to stock but eaten during dry times. Den.

B. patenticuspis R.H. Anderson: a "Copper Burr". Restricted to perimeter of Riverine Plain to the north and west and to outliers of light soil extending into the Plain. Spiny fruits ensure its utilization only in times of stress. Den.

B. quinquecuspis (F. Muell.) F. Muell. var. quinquecuspis:

var. semiglabra Ising:

var. villosa (Benth.) J.M. Black: "Black Roly-poly". Widespread and very common on all but sandy soils, the density of these taxa, which are usually quite distinct from each other, increases on heavily grazed areas such as stock routes. Moderately palatable when young but unacceptable after the formation of spines. Den. 
B. stelligera (F. Muell.) F. Muell. ex Benth.: "Star Bush". Widespread and may be locally common, particularly in saltbush communities. Apparently not highly palatable. Den.

B. tricuspis (F. Muell.) R.H. Anderson: "Three-spined Roly-poly". Occurs throughout all saltbush communities and may form dense stands in overgrazed saltbush pastures. Unpalatable and very spiny when mature. Den.

\section{Chenopodium L.}

*C. album L.: "Fat Hen". A weed of habitation and neglected cultivation, mainly restricted to the higher rainfall areas of the southern Riverine Plain. Occasionally grazed when young but generally regarded as a weed. Den.

C. carinatum R. Br.: "Keeled Goosefoot". Widespread and common on loams and sand-loams. Aromatic and apparently unpalatable as it is rarely grazed when other forage is available. C. pumilio, once considered a separate species, is now regarded as a form of C. carinatum. Den.

C. pseudomicrophyllum Aellen: Occasional occurrence in south-eastern districts, not noted elsewhere. Den.

*C. murale L.: "Nettle-leaved Goosefoot". Common on roadsides and in waste places in southern districts, usually more prevalent on the lighter soil types. Not readily acceptable to stock. Den.

C. nitrariaceum (F. Muell.) F. Muell. ex Benth.: "Nitre Goosefoot", "Indigo Bush". Very widespread and common, particularly in depressions and drainage lines subject to occasional inundation. Not highly palatable but provides good quality forage during drought. Den.

C. polygonoides (J. Murr) Aellen: Apparently rare, collected from near Deniliquin and near Hay. NSW.

C. ulicinum Gandoger: One collection from near Mossgiel. NSW.

C. sp.: A plant with a strong and unpleasant trimethylamine odour. Fairly common in grassland pastures on clay-loam soils in Deniliquin area. Den.

\section{Enchylaena $\mathrm{R}$. Br.}

E. tomentosa R. Br.: "Ruby Saltbush". Widespread and common in most communities, preferring loams and sandy-loams. Fairly palatable and provides forage during drought. Den.

\section{Maireana Moq. (= Kochia Roth.)}

M. aphylla (R. Br.) P.G. Wilson: "Cotton Bush". Widespread throughout the Riverine Plain, becoming the dominant in some areas, particularly in the Deniliquin-Balranald-Hay region. Not highly palatable, particularly when the leaves have fallen, but it provides some forage during dry times. Den.

M. brevifolia (R. Br.) P.G. Wilson: "Short-leaved Bluebush". Widespread but rarely common except in areas of loam soil subject to occasional flooding and on light soils of a calcareous nature. Moderately palatable. Den.

M. cheelii (R.H. Anderson) P.G. Wilson: "Chariot Wheels". Occurrence apparently restricted to saltbush plains of the Deniliquin-Hay region. Not grazed to any extent unless other forage is in short supply. Den.

M. decalvans (Gandoger) P.G. Wilson (= Kochia tomentosa F. Muell. var. tenuifolia (Benth.) J.M. Black): "Black Cotton Bush". Not common and apparently 
restricted to the grasslands in the south and east of the Riverine Plain. Moderately palatable. Den.

M. enchylaenoides (F. Muell.) P.G. Wilson (= Duriala villosa (F. Muell.) Ulbr.): Common in localized areas on loam and clay-loam soils in southern and eastern districts. Den.

M. excavata (J.M. Black) P.G. Wilson: "Bottle Fissure Weed". Widespread, particularly in southern and eastern districts but rarely common except in grasslands on clay-loam soils. Usually grazed only in stress periods. Den.

M. humillima (F. Muell.) P.G. Wilson: Locally common on clay-loams in Deniliquin area-probably occurs to the north and east also. Den.

$M$. microcarpa (Benth.) P.G. Wilson: Recorded from near Oxley. NSW.

M. microphylla (Moq.) P.G. Wilson: (=K. tamarascina auct. non (Lindl.) J.M. Black): "Eastern Cottonbush". Occasional occurrence in DeniliquinTocumwal districts, elsewhere rare. Den.

M. pentagona (R.H. Anderson) P.G. Wilson: "Slender Fissure Weed". Distributed throughout grassland and saltbush communities, very common in DeniliquinHay region on clay and clay-loam soils. A useful forage plant during stress periods. Den.

M. pyramidata (Benth.) P.G. Wilson: "Black Bluebush". Localized communities occur on light calcareous soils throughout the Riverine Plain, becoming more prevalent to the north and west. Whilst not particularly palatable the bush is utilized to some extent during drought. Den.

M. sedifolia (F. Muell.) P.G. Wilson: "Pearl Bluebush". Not as widespread or common in the Riverine Plain as $M$. pyramidata, being confined mainly to the western regions where scattered bushes may occur in association with $M$. pyramidata. Grazed only in stress periods. Den.

\section{Malacocera R.H. Anderson}

M. tricornis (Benth.) R.H. Anderson: "Soft-horned Saltbush". Relatively common on the saltbush plains, elsewhere uncommon. Palatable, usually grazed before the saltbush. Den.

\section{Pachycornia Hook. f.}

P. tenuis (Benth.) J.M. Black: a "Glasswort". Distribution restricted to the saltbush plains, where it may be common in roadside drains, depressions and somewhat saline situations. Apparently unpalatable. Den.

\section{Rhagodia R. Br.}

R. nutans R. Br.: "Climbing Saltbush". Two forms of this plant are known to occur in the area. Very widespread and common in all communities, more frequent in shaded and protected situations. Palatable-a useful forage species. Den.

R. spinescens R. Br.: "Thorny Saltbush". Widesfread and common in most communities, preferring loam and clay-loam soils. Relatively palatable and provides forage during drought. Den.

\section{Salsola L.}

S. kali L. var, kali: "Soft Roly-poly", "Buckbush". Widespread, common on sands and sandy-loams, where it may be the dominant vegetation. The young 
plants are grazed by sheep but they are generally ignored when the spines have hardened. Den. Var. strobilifera Benth. almost certainly occurs in the area, but no specimens have been collected.

\section{Scleroblitum Ulbr.}

S. atriplicinum (F. Muell.) Ulbr. (= Chenopodium atriplicinum (F. Muell.) F. Muell.): "Purple Goosefoot". Widespread and common on clay and clay-loam soils in years of higher rainfall, otherwise restricted to flooded areas and depressions. Palatable when young, suspected (without conclusive proof) of stock poisoning. Den.

\section{Suaeda Forsk.}

$S$. sp.: Common on saline soil in irrigation area near Tullakool, where few other plants can persist. Apparently unpalatable. Den.

\section{AMARANTHACEAE}

Alternanthera Forsk.

A. denticulata R. Br.: "Lesser Joyweed". Widespread, though more prevalent to the south and east with a preference for loam and clay-loam soils. Palatable but of limited value. Den.

*A. pungens Kunth: "Khaki Weed". Weed, confined to areas of habitation in southern and eastern districts and becoming more prevalent. Moderately palatable. Den.

\section{Amaranthus L.}

*A. albus L.: "Tumbleweed". A weed of habitation, common in yards of Deniliquin Railway Station. Den.

*A. hybridus L. sens. lat.: "Slim Amaranth". A weed of home gardens and waste places. Unpalatable. Den.

A. macrocarpus Benth.: Uncommon, collected $40 \mathrm{~km}$ south-west Deniliquin, distribution unknown. Den.

*A. retroflexus L.: One collection, from railway yards, Deniliquin. Den.

*A. viridis L.: "Green Amaranth". A weed on waste land and cultivated areas. Not grazed. Den.

\section{Boerhavia L.}

B. diffusa L.: "Tar-vine". Widespread and common on all soil types and in most communities. Palatable and of some forage value. Den.

\section{Ptilotus R. Br.}

$P$. atriplicifolius (A. Cunn. ex Moq.) Benl var. atriplicifolius: Only collection from loam soil, Coleambally Irrigation District. Den.

$P$. erubescens Schlecht.: One collection, from roadside near Hill Plain, 1954 . NSW.

$P$. exaltatus Nees var. semilanatus (Lindl.) Maid. et Betche $(=P$. semilanatus (Lindl.) F. Muell. ex Black): "Lamb Tails". Common on brown clay and loam soils in the southern and eastern districts. Palatable and provides useful forage. Den.

P. macrocephalus (R. Br.) Poir.: Collected from near Bundure siding, $40 \mathrm{~km}$ north of Jerilderie, on red clay soil. NSW. 
P. nobilis (Lindl.) F. Muell.: "Yellow Tails". Occasional occurrence in Wanganella district. NSW.

P. spathulatus (R. Br.) Poir.: “Pussy Tails". Occurs frequently on clay-loam and loam soils in grassland pastures. Palatable. Den.

\section{AIZOACEAE}

Disphyma N.E. Br.

D. clavellatum (Haw.) Chinnock ( $=$ D. blackii Chinnock; D. australe (Soland). J.M. Black): "Pigface". Common in scattered areas throughout saltbush country. It occurs on most soil types but is more prevalent on the heavy clays. Not palatable but may be grazed sparingly in times of stress. Den.

\section{Galenia L.}

*G. secunda (L. f.) Sond.: Occasional occurrences on loam and clay soils in southern areas. Den.

\section{Glinus L.}

G. lotoides L.: "Hairy Carpet-weed". Widespread but common only in localized areas, most frequently occurring on soil from which water has receded or dried up. Den.

\section{Mesembryanthemum $\mathbf{L}$.}

*M. crystallinum L.: (= Gasoul crystallinum (L.) Rothm.) “Ice-plant”. Infrequent, found only in years of high rainfall on sandy-loam soils where competition has been reduced by cultivation or by previous heavy grazing. Den.

\section{Sarcozona J.M. Black}

S. praecox (F. Muell.) S.T. Blake: Locally common in patches throughout saltbush country. Apparently not highly palatable. Den.

\section{Tetragonia L.}

T. tetragonioides (Pall.) Kuntze: "New Zealand Spinach". Widespread and common in years of good rainfall, growing on most soil types. Palatable and regarded as good fodder. Den.

\section{Trianthema L.}

T. galericulata Melville: Locally common in small areas on sandy-loam and loam soils near Deniliquin. Relatively unpalatable. Den.

T. triquetra Willd.: Widespread and fairly common in years of high rainfall. Den.

\section{PORTULACACEAE \\ Calandrinia Kunth}

C. eremaea Ewart: "Small Purslane". Common on sandy-loam soils in eastern areas. Probably palatable. Den.

C. volubilis Benth.: "Twining Purslane". Common throughout the saltbush country where it is found growing around the bases of the bushes. Palatable but protected to some extent by the bushes. Den. 


\section{Portulaca L.}

$P$. oleracea L.: "Pigweed". Wide distribution throughout the Riverine Plain on loams and clay-loams and occurring in almost all communities. Palatable and provides summer forage in years of suitable rainfall. Den.

\section{CARYOPHYLLACEAE}

Cerastium L.

*C. glomeratum Thuill.: "Mouse-ear Chickweed". Common in house gardens and waste places; isolated occurrences in woodlands in southern areas. Den.

\section{Petrorhagia (Ser. ex DC.) Link}

*P. velutina (Guss.) Ball et Heywood: "Velvet Pink". Locally common in southern areas, particularly during good years. Den.

\section{Polycarpon L.}

*P. tetraphyllum (L.) L.: “Four-leaf All-seed". A common weed of garden paths and lawns-infrequent elsewhere. Den.

\section{Silene L.}

*S. gallica L.: "Catchfly". Collected from eastern boundary of Riverine Plain, near Narrandera, on sandy-loam and from "Zara", Wanganella. Den.

\section{Spergularia (Pers.) J. et C. Presl}

*S. rubra J. et C. Presl sens. lat: "Sand Spurry". Very widespread and common in all communities. A useful primary colonizer of bare soil. Palatable. Den.

\section{Stellaria L.}

S. angustifolia Hook.: "Swamp Starwort". Collected from swamp near Wanganella, possibly occurs elsewhere in similar situations. Den.

*S. media (L.) Vill.: "Chickweed". Weed of gardens and lawns, occasionally spontaneous in woodlands. Den.

Vaccaria Med.

*V. pyramidata Med.: "Bladder Soapwort". One collection from wheat crop near Barham. Den.

\section{RANUNCULACEAE}

Clematis $\mathrm{L}$.

C. microphylla DC. var. microphylla: "Narrow-leaved Clematis". Climber now restricted to relatively undisturbed areas of woodland on sandy-loam and loam soils, where it may be locally common. Den.

Myosurus L.

M. minimus L. sens. lat.: "Mouse-tail". Widespread and relatively common on clay-loams and clays in years of good autumn and winter rainfall. Palatable. Den. 
Ranunculus L.

R. inundatus R. Br. ex DC.: “River Buttercup". Found in low-lying areas along the Murray system. Den.

R. lappaceus Sm.: "Buttercup". Widespread and locally common in swampy habitats in southern and eastern districts. Den.

*R. muricatus L.: "Sharp Buttercup". Common in swamps in southern areas. Den.

$R$. papulentus Melville: Collected from swamp at "Ulonga", near One Tree. Distribution unknown. Den.

R. pentandrus J.M. Black var. platycarpus (F. Muell.) Hj. Eichler: "Smooth Buttercup". Widespread and common, particularly in years of good autumn and winter rainfall, on a wide variety of soils. Not particularly palatable but eaten at times. Den.

R. pumilio R. Br. ex DC. var. pumilio: One record from Murrumbidgee River near Hay, possibly overlooked elsewhere. NSW.

var. politus Melville: Common in years of higher rainfall. Found on clays and loams in southern areas. Relatively unpalatable. Den.

R. undosus Melville: Locally common in swamp near Wanganella. Distribution unknown. Den.

\section{PAPAVERACEAE}

Papaver L.

*P. hybridum L.: "Rough Poppy". A weed of cultivated land, extending into native pastures during good rainfall years. Unpalatable but suspected of causing stock disorders when fed in conserved fodder. Den.

\section{FUMARIACEAE}

Fumaria L.

${ }^{*} F$. bastardii Boreau: One collection from Millewa State Forest where locally common on clay soils. Den.

*F. densiflora DC.: "Dense Fumitory". Widespread on loam soils, though rarely common. Den.

\section{BRASSICACEAE ( $=$ CRUCIFERAE) \\ Alyssum L.}

A. linifolium Steph. ex Willd.: Common in northern areas in years of good rainfall. Den.

Arabidella (F. Muell.) Schulz

A. nasturtium (F. Muell.) E. Shaw (= Blennodia nasturtioides (F. Muell.) Druce): "Yellow Cress". Widespread, more abundant in northern districts, usually on loam and clay-loam soils. Palatable. Den.

\section{Brassica L.}

*B. tournefortii Gouan: "Wild Turnip". A widespread weed of roadsides and waste places, found on a wide variety of soils. Unpalatable. Den.

Capsella Medik.

*C. bursa-pastoris (L.) Medik.: "Shepherd's Purse". Widespread, most frequent on loam and clay-loam soils. Rarely utilized. Den. 
Cardaria Desv.

*C. draba (L.) Desv.: "Hoary Cress". Weed of gardens and roadsides, not common except in occasional patches. Den.

\section{Coronopus Zinn.}

*C. didymus (L.) Sm.: "Lesser Swinecress". Occasional weed of cultivation areas. Den.

Diplotaxis DC.

*D. tenuifolia (L.) DC.: "Sand Rocket". Weed, common in Deniliquin Railway yards. Den.

Geococcus Drumm. ex Harv.

G. pusillus Drumm. ex Harv.: "Earth Cress". Widespread, common in years of good rainfall. Den.

\section{Harmsiodoxa Schulz}

H. blennodioides (F. Muell.) Schulz (= Blennodia blennodioides (F. Muell.) Druce): "Hairy Cress". Occasional plants on light soils in northern areas, more frequent in country bordering northern and western districts. Moderately palatable. Den.

\section{Hirschfeldia Moench}

*H. incana (L.) Lagrèze-Fossat: "Buchan Weed". Weed of cultivation areas and roadsides. Den.

\section{Lepidium L.}

L. fasciculatum Thell.: "Bundled Peppercress". Widespread and common, with a preference for loam and clay-loam soils. Moderately palatable. Den.

L. hyssopifolium Desv.: "Peppercress". Widespread and common in all communities, more prevalent in southern districts. Relatively unpalatable but eaten during dry periods. Den.

L. monoplocoides F. Muell.: “Winged Peppercress". One record from CSIRO Falkiner Memorial Field Station in 1945. Den.

L. papillosum F. Muell.: Locally common in clay soil west of Mossgiel, distribution unknown. Den.

\section{Menkea Lehm.}

M. australis Lehm.: "Fairy Spectacles". Widespread in northern districts where it may be locally common. Den.

\section{Phlegmatospermum Schulz}

$P$. cochlearinum (F. Muell.) Schulz: Locally common in northern districts. Den.

\section{Raphanus L.}

* $R$. raphanistrum L.: "Wild Radish". Occasional weed of roadsides and waste places. Den. 


\section{Rapistrum Crantz}

*R. rugosum (L.) All.: “Turnip-weed". Weed of cultivated land and waste places. Den.

\section{Rorippa Scop.}

R. laciniata (F. Muell.) L. Johnson: Locally common in southern areas, usually in depressions on clay soils. Den.

\section{Sisymbrium L.}

*S. erysimoides Desf.: "Smooth Mustard". Widespread weed which may be locally common, particularly in areas of high fertility such as sheep camps, and in leaf mulch beneath trees. Unpalatable. Den.

*S. irio L.: "London Rocket". Widespread, common in years of good rainfall, on most soil types. Unpalatable. Den.

*S. orientale L.: "Indian Hedge Mustard". Widespread weed in crops, fallows and waste places, on a variety of soils. Relatively unpalatable. Den.

Stenopetalum R. Br. ex DC.

S. velutinum F. Muell. Recorded from Wanganella, 1903. NSW.

\section{RESEDACEAE}

Reseda L.

*R. luteola L.: "Wild Mignonette". Weed of cultivated areas and roadsides in southern districts. Rarely eaten, suspected (without conclusive evidence) of poisoning stock. Den.

\section{CRASSULACEAE}

\section{Crassula L.}

C. colorata (Nees) Ostenf.: "Dense Stonecrop". Widespread in all communities. Of little forage value because of small size. Den.

C. helmsii (T. Kirk) Cockayne: Widespread, usually growing in mud or water. Den.

C. macrantha (Hook. f.) Diels et Pritzel: "Rufous Stonecrop". One collection from Deniliquin area, distribution unknown. Den.

C. purpurata (Hook. f.) Domin: "Purple Stonecrop". Widespread and common, particularly in moist places, often overlooked because of its small size. Den.

C. sieberana (Schultes et f.) Druce: "Austral Stonecrop". Widespread in all communities. Of little or no value because of its small size. Den.

\section{PITTOSPORACEAE}

Bursaria Cav.

B. spinosa Cav.: "Australian Blackthorn". Widespread in southern districts, usually occurs as shrub or small tree along roadsides and in lightly grazed areas on loam soils. Den.

Pittosporum Banks ex Gaertn.

P. phylliraeoides DC,: "Berrigan". Widespread tree, sparse occurrence on light soils. Den. 


\section{ROSACEAE}

\section{Aphanes L.}

A. australiana (Rothm.) Rothm.: Collected only from Deniliquin area where locally common in years of high rainfall. Den.

\section{Poterium L.}

*P. polygamum Waldst. et Kit.: One collection from Coleambally Irrigation Area. Den.

Rosa L.

*R. canina L.: "Dog Rose". One collection from river flat near Barham. First record of this as naturalized in N.S.W. Den.

\section{Rubus L.}

*R. fruticosus L., sens. lat.: "Blackberry". Collected from frontage of Murray River near Picnic Point, east of Mathoura. Den.

\section{MIMOSACEAE}

Acacia Mill.

A. acinacea Lindl: "Gold-dust Acacia". Locally common on a range of soil types in the southern Riverine Plain. Den.

A. aneura F. Muell. ex Benth.: "Mulga". Recorded from Hay, 1886. Not known to occur now on the Riverine Plain. NSW.

$A$. brachybotrya Benth.: Widespread and locally common on sandy ridges. Den.

A. colletioides Benth.: Recorded from Hay, 1886. A common shrub in country to the north of the Riverine Plain but doubtful if present on the Plain today. NSW.

A. dealbata Link: One collection, from bank of Murray River near Barham, where locally common. Den.

A. decora Reichenb.: "Western Silver Wattle". Recorded from Jerilderie, 1916. NSW.

*A. farnesiana (L.) Willd.: One record, from $35 \mathrm{~km}$ north of Jerilderie. NSW.

A. hakeoides A. Cunn. ex Benth.: "Western Black Wattle". Apparently restricted to south-eastern districts, where it may be common locally, particularly on loam soils. Den.

A. homalophylla A. Cunn. ex Benth.: "Yarran". Widespread and locally common, restricted to light soils. Den.

A. lineata A. Cunn. ex G. Don: "Streaked Acacia". Only known occurrence near Lalalty School in extreme south-east, where common. Den.

A. loderi Maiden: "Neelie". Occasional occurrences on light soils in northern districts. NSW.

A. montana Benth.: "Mallee Acacia". Occasional plant in Tocumwal-Berrigan district. Den.

A. osswaldii F. Muell.: "Miljee". Widespread, occurring as occasional trees on the lighter soil types. Den. 
A. pendula A. Cunn. ex G. Don: "Boree" or "Myall". Widespread though more common in south eastern districts where it may be the dominant tree species on areas of clay-loam soils. A useful drought fodder. Its health and appearance invariably affected by the larvae of the bag-shelter moth. Den.

A. pycnantha Benth.: "Broad-leaved Wattle". Isolated occurrences in TocumwalBerrigan area. Den.

A. salicina Lindl.: "Cooba" or "Native Willow". Widespread, common along water courses and on the sandy ridges of prior streams. Den.

A. stenophylla A. Cunn. ex Benth.: "River Cooba". Common along banks of most streams and in some low-lying situations. Den.

A. victoriae Benth.: "Prickly Wattle". Uncommon, restricted to light soils in western and northern districts. Den.

\section{CAESALPINIACEAE}

Cassia L.

C. eremophila A. Cunn. ex Vogel var. coriacea (Benth.) Symon: "Desert Cassia". Widespread, may be locally common on sandy-loam soils. Of some fodder value during drought. Den.

var. eremophila: "Punty Bush". Widespread on sand and loam soils, less common than var. platypoda. Den.

var. platypoda (R. Br.) Benth.: "Punty Bush". Widespread, locally common on sandy-loam soils. Browsed at times. Den.

\section{FABACEAE $(=$ PAPILIONACEAE)}

Alhagi Gagnebin

*A. pseudalhagi (Bieb.) Desv. (=A. camelorum Fisch.): "Camel Thorn". One collection, from Moulamein, 1947. A noxious weed. NSW.

Eutaxia R. Br. ex Ait.

E. microphylla (R. Br. ex Ait.) J.M. Black: "Eutaxia". Relatively uncommon, apparently restricted to woodlands in southern and eastern districts. Den.

\section{Glycine L.}

G. clandestina Wendl.: "Twining Glycine". Restricted to the south-eastern districts, where it may be locally common. Palatable. Den.

\section{Glycyrrhiza L.}

G. acanthocarpa (Lindl.) J.M. Black: "Native Liquorice". Widespread, occasionally locally common in favourable situations. Palatable, but a nuisance in sheep country because its burry seed-pods contaminate wool. Den.

Lotus L.

L. australis Andr.: "Austral Trefoil". Recorded in southern and eastern districts, distribution uncertain. Palatable, may at times be poisonous to stock. Den.

L. cruentus Court: "Red-flowered Trefoil". Widespread and common on light soils. Palatable, probably poisonous to stock at times. Den.

The above two species may hybridize. 


\section{Medicago L.}

*M. laciniata (L.) Mill.: "Cut-leaved Medic". Widespread, but more common in northern and western districts, usually most plentiful on light soils. Palatable, but the spiny burrs may contaminate wool. Den.

*M. minima (L.) Bart.: "Woolly Burr Medic". Widespread and common, mainly on light soils but may also occur on the puffs of gilgais. Palatable, with spiny burrs which contaminate wool. Den.

*M. polymorpha L. var. vulgaris (Benth.) Shin.: "Burr Medic". Widespread and very common on a range of soil types, reaching maximum size and density on grey clay soils. Palatable and a valuable fodder plant despite the nuisance value of its burr as a contaminant of wool. Den.

*M. praecox DC.: "Small-leaved Burr Medic". Collected from Hay and Wakool districts but distribution and abundance uncertain because of similarity to the very common $M$. polymorpha. NSW.

*M. truncatula Gaertn. var. longispina Urb.: "Barrel Medic". Widespread and fairly common, particularly on clay soils. Palatable and a useful contributor to winter-spring forage. Not a serious contaminant of wool as the spines of the pods are relatively short. Den.

Melilotus Mill.

*M. indica (L.) All.: "Hexham Scent". Apparently restricted to southern and eastern districts, where it may be an escape from irrigated pastures. Palatable. Den.

\section{Prosopis L.}

*P. juliflora (Sw.) DC.: "Mesquite". One record from near Barham. Den.

\section{Psoralea L.}

$P$. cinerea Lindl.: One collection from swamp near Booroorban. Distribution unknown. Den.

$P$. tenax Lindl.: Recorded from $34 \mathrm{~km}$ south of Jerilderie. Den.

Swainsona Salisb.

S. murrayana Wawra ssp. eciliata A. Lee: Only one known collection, from "Zara" near Wanganella in 1905. NSW.

spp. murrayana: "Slender Swainsona". Widespread, though more common on clay and clay-loam soils in south-eastern districts. Palatable. Den.

S. oroboides F. Muell. ex Benth. ssp. reticulata (J.M. Black) A. Lee: and ssp. sericea A. Lee: Both subspecies are apparently confined to clay and clay-loam soils in the southern and eastern districts, where they may be common. Palatable. Den.

S. phacoides Benth. ssp. phacoides: "Dwarf Swainsona". Widespread, but restricted to sands and sandy-loams. Palatable. NSW.

S. plagiotropis F. Muell.: One collection from near Jerilderie, distribution unknown. Den.

S. procumbens (F. Muell.) F. Muell.: "Broughton Pea". Widespread and common on a wide range of soils, more prevalent in moist sites on clay and clay-loam soils. Palatable, but may cause a disease known as "pea-struck" or "locodisease" in sheep when eaten in quantity. Den. 
S. swainsonioides (Benth.) A. Lee: "Downy Swainsona". Widespread, most common in moist situations on clay soils. Palatable, but may cause "peastruck" or "loco-disease" in sheep. Den.

\section{Templetonia R. Br.}

T. egena (F. Muell.) Benth.: "Desert Broombush". Uncommon, known only from Moulamein area, where it occurs as scattered plants on calcareous clay. Relatively unpalatable. Den.

\section{Trifolium L.}

${ }^{*} T$. angustifolium L.: "Narrow-leaved Clover". Found only in southern areas where it may be locally common. Den.

*T. arvense L.: "Haresfoot Clover". Common only in southern and eastern districts where it is restricted to sandy soils. Palatable. Den.

*T. campestre Schreb.: "Hop Clover". Found on river flat near Deniliquin, where common, distribution otherwise unknown. Den.

*T. cernuum Brot.: "Drooping-flowered Clover". Occurs in localized areas between Deniliquin and Tocumwal. Palatable. Den.

*T. glomeratum L.: "Clustered Clover". Widespread, but common only in southern districts. Palatable. Den.

*T. tomentosum L.: "Woolly Clover". Widespread, though relatively uncommon, occurring on a range of soil types. Palatable. Den.

Trigonella L.

${ }^{*} T$. ornithopodioides (L.) DC.: Recorded from Barham, Berrigan and Deniliquin. Apparently very palatable. NSW.

T. suavissima Lindl.: “Cooper Clover". Locally common on flooded country of the lower Lachlan River. Rare elsewhere. Palatable. Den.

Vicia L.

*V. sativa L.: "Common Vetch". Found on river flats in southern areas where it may be common. Palatable. Den.

\section{GERANIACEAE}

Erodium L'Hérit.

*E. botrys (Cav.) Bertol.: "Long Storksbill". Distribution apparently restricted to the more favoured southern districts, where it may be common. Relatively unpalatable, with sharp pointed seeds which penetrate and damage the flesh of sheep. Den.

*E. cicutarium (L.) L'Hérit. ex Ait.: “Common Crowfoot”. Widely distributed on all soil types. Palatable and a useful forage species. Den.

E. crinitum Carolin: "Blue Crowfoot". Widespread on most soil types, in favourable years occurring as dense pure stands on sandy soils. Relished by stock and provides excellent forage. Its sharp pointed seeds can cause damage to sheep. Den.

*E. moschatum (L.) L'Hérit. ex Ait.: “Musky Crowfoot”. Generally confined to southern districts where it may be locally common, particularly on loam soils. 
Relatively unpalatable, probably on account of its musky odour and taste, but eaten at times. Den.

\section{Geranium L.}

G. retrorsum L'Hérit. ex DC.: Uncommon, occasional plants occurring on clay soils in favourable years. Den.

G. solanderi Carolin var. solanderi: One collection from sandy-loam soil $48 \mathrm{~km}$ south-east of Deniliquin. Den.

\section{OXALIDACEAE}

Oxalis L.

O. corniculata L.: "Yellow Wood Sorrel". Widespread but infrequent on all soil types, preferring moister and shadier sites. Palatable. Den.

*O. pes-caprae L.: "Soursob", "Yellow Oxalis". A widespread weed of habitation. Den.

\section{LINACEAE}

\section{Linum L.}

L. marginale A. Cunn. ex Planch.: "Wild Flax". Uncommon, occasional plants occurring in southern districts. Den.

\section{ZYGOPHYLLACEAE}

Nitraria L.

N. billardieri DC. ( $=N$. schoberi auctt. austral. non L.): "Dillon Bush", "Nitrebush". Widespread and common, with a preference for heavier soil types. Attains maximum size in degenerate saltbush communities. The leaves are not readily grazed by stock, but the fruits are apparently more acceptable and eaten by sheep, native animals and birds. Den.

\section{Tribulus L.}

*T. terrestris L.: "Cat-head", "Caltrops". Widespread weed, most common on light sandy-loams. Unpalatable, suspected of poisoning stock, bears troublesome spiny fruits. Den.

\section{Zygophyllum L.}

Z. ammophilum F. Muell.: Recorded from Wanganella, 1903. NSW.

Z. apiculatum F. Muell.: “Gall-weed”. Restricted to sandy-loam soils in western districts where it is fairly common. Relatively unpalatable. Den.

Z. glaucum F. Muell. (= Z. glaucescens F. Muell.): “Pale Twin-leaf”. Generally confined to western districts where it may be locally common on sandy soil. Palatable. Den.

Z. iodocarpum F. Muell.: "Violet Twin-leaf". Recorded from Hay district, possibly occurs elsewhere in northern districts. Palatable. NSW.

\section{RUTACEAE}

\section{Geijera Schott}

G. parviflora Lindl.: "Wilga". Widespread, though uncommon, occurring as occasional trees on areas of sandy-loam soils. Of variable palatability. Den. 


\section{EUPHORBIACEAE}

Euphorbia L.

E. drummondii Boiss.: "Caustic Weed". Widespread and common on all soil types. Palatable, may at times be toxic to sheep. Den.

E. eremophila A. Cunn. ex Hook.: "Desert Spurge". Widespread on a range of soils with dense populations occurring after heavy summer rain on self-mulching clays. Moderately palatable, suspected of being poisonous to stock. Den.

*E. peplus L.: "Petty Spurge". A weed restricted to areas of habitation. Den.

\section{Phyllanthus L.}

$P$. lacunarius F. Muell.: “Lagoon Spurge”. Collected from clay soil near Conargo, distribution unknown. Den.

\section{CALLITRICHACEAE}

Callitriche $\mathrm{L}$.

*C. stagnalis Scop.: "Water Starwort". Widespread amphibious plant, common in swamps and areas subject to inundation. Den.

\section{STACKHOUSIACEAE}

Stackhousia $\mathrm{Sm}$.

S. monogyna Labill.: "Creamy Stackhousia". Confined to sandy-loam soil in Narrandera area. Den.

\section{SAPINDACEAE}

Dodonaea L.

D. attenuata A. Cunn.: "Narrow-leaved Hop-bush". Widespread, with habitat restricted to light soils. Dense thickets may occur on sand ridges. Relatively unpalatable. Den.

D. cuneata Sm.: "Wedge-leaved Hop-bush". Occasional plants on loam soils near Tocumwal. Not known to occur elsewhere. Den.

\section{Heterodendrum Desf.}

H. oleifolium Desf.: "Rosewood", "Bullock-bush". Widespread and relatively common, restricted to soils of light texture, where it may occur in groves. Regenerates only from suckers. A useful forage tree which is relished by both sheep and cattle. Den.

\section{MALVACEAE}

Abutilon Mill.

A. halophilum F. Muell.: a "Chinese Lantern". Uncommon except in localized areas on saltbush plains. Moderately palatable. Den.

A. theophrasti Medik.: "Swamy Chinese Lantern". Uncommon, though possibly widespread; habitat apparently restricted to damp situations. Den. 


\section{Hibiscus L.}

*H. trionum L.: "Bladder Ketmia". Generally uncommon except after heavy rains. Distribution restricted to southern and eastern districts. Den.

\section{Lavatera L.}

L. plebeia Sims: "Australian Hollyhock". Widespread, frequently found in depressions and areas subject to occasional inundation. Palatable. Suspected of poisoning stock. Den.

\section{Malva L.}

*M. parviflora L.: "Small-flowered Mallow”. Widespread and common, particularly in areas of habitation. Relatively unpalatable, suspected of causing stock disorders. Den.

\section{Modiola Moench}

*M. caroliniana (L.) G. Don: "Red-flowered Mallow". A plant of habitation, occurring in gardens and irrigated areas, rarely in natural pastures. Den.

\section{Sida L.}

$S$. corrugata Lindl.: "Corrugated Sida". Widespread and common throughout, on a wide variety of soils. Very palatable. Den.

S. fibulifera Lindl.: "Pin Sida". Occasional occurrence on clay and loam soils. Palatable. Den.

S. intricata F. Muell.: "Tangled Sida". Generally confined to areas of sandy-loams or calcareous clays in northern and western districts. Moderately palatable. NSW.

S. trichopoda F. Muell.: "High Sida". Widespread and common, preferring clay and clay-loam soils. Palatable. Den.

\section{HYPERICACEAE}

\section{Hypericum L.}

H. japonicum Thunb.: "Matted St John's Wort". One collection from forest bordering Murray River between Mathoura and Tocumwal, where common. Distribution unknown but possibly occurs in similar situations elsewhere. Den.

*H. perforatum L.: “St John's Wort”. Collected from roadside near Berrigan, where it occurred as a small isolated patch. A weed which has been shown to cause stock disorders. Den.

\section{ELATINACEAE}

\section{Elatine L.}

*E. gratioloides A. Cunn.: "Waterwort". One collection from swamp at "Ulonga", north west of Hay but undoubtedly occurring in similar situations elsewhere.

Den.

\section{FRANKENIACEAE}

\section{Frankenia L.}

$F$. connata Sprague: Widespread throughout saltbush communities though rarely common. Den.

F. latior Sprague et Summerh.: Recorded from "Zara", Wanganella, 1917. NSW. 


\section{VIOLACEAE}

Viola L.

$V$. betonicifolia Sm.: "Purple Violet". Recorded as scattered plants in Millewa State Forest, between Mathoura and Tocumwal. Den.

THYMELAEACEAE

Pimelea Banks et Sol. ex Gaertn.

P. microcephala R. Br.: "Small-headed Rice-flower". Widespread though uncommon, restricted to low woodland communities on sands and loams. Den.

\section{LYTHRACEAE}

Ammannia L.

A. multiflora Roxb.: "Jerry-jerry". Collected from Black Swamp near Wanganella and probably occurs in low-lying situations throughout. Den.

\section{Lythrum L.}

L. hyssopifolia L.: "Hyssop Loosestrife". Widespread and common in low-lying areas subject to occasional flooding. Unpalatable. Den.

L. salicaria L.: "Purple Loosestrife". One collection from $40 \mathrm{~km}$ south of Deniliquin. Not noted elsewhere, distribution unknown. Den.

\section{MYRTACEAE}

Callistemon R. Br.

C. brachyandrus Lindl.: "Prickly Bottle-brush". Only known occurrence on Eurolie Road, between Hay and Conargo, where locally common. Den.

Calytrix Labill.

C. tetragona Labill.: "Common Fringe-myrtle". Collected from sandhill in Millewa State Forest, where common. Den.

Eucalyptus L'Hérit.

E. camaldulensis Dehnh.: “River Red Gum”. Widespread species generally confined to the proximity of streams and drainage lines. An important commercial timber. Den.

E. dumosa A. Cunn. ex Schau.: "Congoo Mallee”. Restricted to outliers of Mallee vegetation on the western margins of the Plain. Den.

E. largiflorens F. Muell.: "Black Box". Widespread and common, usually in low-lying areas. Den.

E. leucoxylon F. Muell.: "Yellow Gum". Only known to occur in one small clump on outskirts of Barham. Den.

E. melliodora A. Cunn. ex Schau.: "Yellow Box". Common on loam soils in southern and eastern districts. Den.

E. microcarpa (Maiden) Maiden: "Inland Grey Box". Restricted to southern and eastern districts. Grows on a range of soil types but appears to be more plentiful on loams and clay-loams. Den. 
E. porosa F. Muell. ex Miq.: “Black Mallee Box". Recorded from Moulamein district. NSW.

E. socialis F. Muell. ex Miq.: "Red Mallee". Several trees on loam soil on "Bundyulumblah" between Wanganella and Moulamein. Possibly similar isolated occurrences elsewhere on the Riverine Plain. Very common in mallee vegetation along northern and western perimeters of the Plain. Den.

\section{Melaleuca L.}

M. lanceolata Otto: "Black Tea-tree", "Moonah". Widespread and fairly common, its habitat restricted to light sandy soils. Den.

\section{ONAGRACEAE}

\section{Epilobium L.}

E. billardierianum Sér. ssp. cinereum (A. Rich.) Raven et Englehorn ( $=E$. cinereum A. Rich.; E. junceum Sol.): "Hoary Willow-herb". Widespread but not common; restricted to moist, fertile situations. Den.

\section{Ludwigia L.}

L. peploides (Kunth) Raven ssp. montevidensis (Spreng.) Raven: "Water Primrose". A widespread aquatic plant found in shallow ponds, streams and channels. Suspected of causing gastro-enteritis in cattle. Den.

Oenothera L.

*O. affinis Cambess: an "Evening Primrose". Collected from cemetery at Tocumwal and common on sandy soil in that vicinity. Den.

*O. stricta Ledeb. ex Link: "Common Evening Primrose". Found mainly in southern and eastern districts where it is restricted to sand ridges. Unpalatable. Den.

\section{HALORAGACEAE}

Haloragis Forst. et $\mathrm{f}$.

H. aspera Lind1.: Recorded from Hay and from Wakool district. NSW.

H. glauca Lindl.: "Grey Raspwort". Widespread and common on river banks and flats, less abundant in grasslands and saltbush country. Palatable. Den.

$H$. heterophylla Brongn.: a "Raspwort". Widespread though relatively uncommon. Palatable. Den.

\section{Myriophyllum L.}

M.elatinoides Gaudich.: “Coarse Water-milfoil". Widespread aquatic plant growing semi-submerged in static or slow flowing water. Den.

$M$. sp.: Collected from swamp edge in vicinity of Black Swamp, near Wanganella. Possibly common but overlooked elsewhere. The identity of this material needs further checking: the species is otherwise recorded only from northern Australia. Den.

M. propinquum A. Cunn.: "Water-milfoil". Widespread, semi-submerged aquatic plant. Den.

M. verrucosum Lindl.: "Red Water-milfoil". Common aquatic plant of slow moving streams and still water. Den. 
APIACEAE ( = UMBELLIFERAE)

Daucus L.

D. glochidiatus (Labill.) Fisch., Mey. et Avé-Lall.: "Australian Carrot”. Found on clay and loam soils in most communities. Palatable. Den.

Eryngium L.

E. plantagineum F. Muell.: Collected from Deniliquin area. NSW.

E. rostratum Cav.: "Blue Devil". Uncommon except in localized areas in southern districts in years of favourable winter rainfall. Unpalatable. Den.

\section{Hydrocotyle L.}

H. laxiflora DC.: "Stinking Pennywort". Recorded from sandy soil in Millewa State Forest, further distribution unknown. Den.

$H$. sp. (possibly of the $H$. hirta group): Common in localized area on swampy clay in Millewa State Forest. Not noted elsewhere. Den.

\section{PRIMULACEAE}

\section{Anagallis L.}

*A. arvensis L.: "Scarlet Pimpernel". Widespread and locally common in good rainfall years. Both red- and blue-flowered forms occur. Palatable, suspected of poisoning stock. Den.

\section{OLEACEAE}

\section{Jasminum L.}

J. lineare R. Br.: "Desert Jasmine". Widespread though relatively uncommon twiner in protected woodlands on sandy soils. Palatable. Den.

\section{GENTIANACEAE}

Centaurium Hill

C. spicatum (L.) Druce: "Australian Centaury". Uncommon, though may occur in localized areas in southern districts during favourable years. Den.

\section{MENYANTHACEAE}

Nymphoides Séguier

$N$. crenata (F. Muell.) Kuntze: "Wavy Marshwort". Semi-submerged aquatic plant of streams and ponds, possibly restricted to the Murray River system in southern districts. Den.

\section{CONVOLVULACEAE}

Convolvulus L.

*C. arvensis $\mathbf{L}$.: "Field Bindweed". A weed of habitation. Possibly toxic to stock. Den.

C. erubescens Sims: "Australian Bindweed". Widespread, relatively common on a range of types of soils, generally in grasslands and open timber country. Palatable. Den. 


\section{Cressa $\mathbf{L}$.}

C. cretica L.: "Resinweed". Common on saltbush plains and river flats on soils ranging from saline clays to sands. Palatable. Den.

Dichondra Forst. et $\mathrm{f}$.

$D$. repens Forst. et f. sens. lat.: "Kidney-weed". Apparently confined to moist, shady situations in southern districts. Den.

Wilsonia R. Br.

$W$. rotundifolia Hook.: One collection from lake edge $40 \mathrm{~km}$ south-west of Deniliquin. Den.

\section{BORAGINACEAE}

Amsinckia Lehm.

*A. intermedia Fisch. et Mey.: "Yellow Burr-weed". A weed of crop land and thin pasture swards. Den.

\section{Buglossoides Moench}

*B. arvense (L.) Johnston: "Corn Gromwell". A weed of cultivation, extending occasionally into damp situations in natural communities. Den.

\section{Cynoglossum L.}

C. australe R. Br.: "Australian Hound's Tongue". Recorded from Jerilderie, 1920. NSW.

C. suaveolens R. Br.: "Sweet Hound's Tongue". A weed of cultivation, not common. Den.

\section{Echium L.}

*E. plantagineum L. ( $=$ E. lycopsis L.): "Paterson's Curse". Widespread though more common in southern and eastern districts where it is a prevalent weed on light soils. Palatable when young. Den.

\section{Heliotropium L.}

*H. europaeum L.: "Heliotrope". Widespread and common weed, more prevalent on loams and clay-loams in the eastern districts. Prolific stands may occur after good summer rains. Unpalatable but may be eaten in the absence of other more preferred species. Sheep consuming large quantities of this plant over an extended period may suffer liver damage and ultimately die. Den.

*H. supinum L.: a "Heliotrope". Widespread and fairly common, occurring mainly on clay soils. Den.

\section{Lycopsis L.}

*L. arvensis L.: "Wild Bugloss". One collection from Barham. NSW.

\section{Omphalolappula Brand}

O. concava (F. Muell.) Brand: "Burr Stickseed". Recorded from "Zara", Wanganella, 1903. NSW. 
Plagiobothrys Fisch. et Mey.

P. elachanthus (F. Muell.) Johnston: "Hairy Forget-me-not”. Widespread though rarely common, occurring on most soil types. Palatable. Den.

P. plurisepaleus (F. Muell.) Johnston: "White Rochelia". Widespread, may be locally common, found on a range of soil types. Palatable. Den.

\section{VERBENACEAE}

Phyla Lour.

*P. nodiflora (L.) Greene: "Fog-fruit". Garden plant which has become naturalized in damp situations in several natural communities. Den.

\section{Verbena L.}

*V. bonariensis L.: "Purple-top". Occasional weed of habitation and cultivation in southern districts. Den.

*V. officinalis L.: "Common Verbena". Widespread, fairly common in depressions on most soil types. Moderately palatable. Den.

*V. supina L.: One record, from Berrigan. NSW.

\section{LAMIACEAE ( = LABIATAE) \\ Ajuga L.}

A. australis R. Br.: “Australian Bugle”. Widespread though uncommon, occurring on light sandy soils. Den.

\section{Marrubium L.}

*M. vulgare L.: "Horehound". Widespread weed, common on sandy-loams particularly in disturbed situations. Unpalatable, with seed capsules which cling to and contaminate wool. Den.

\section{Mentha L.}

M. australis R. Br.: "River Mint". Occurs on flooded areas near streams and water holes. Unpalatable. Den.

$M$. diemenica Spreng.: "Slender Mint". Distribution restricted to river flats and areas adjacent to streams. Unpalatable. Den.

*M. pulegium L.: "Pennyroyal". Several records from damp situations in southern areas. Den.

M. satureioides R. Br.: "Native Pennyroyal". Widespread and common along streams. Den.

\section{Salvia L.}

*S. verbenaca L.: "Wild Sage". Widespread weed of cultivated land and waste places, usually on sandy-loams. Unpalatable. Den.

\section{Teucrium L.}

T. racemosum $\mathrm{R}$. Br.: "Grey Germander". Widespread and common species throughout, more prevalent on clay-loam and clay soils. Palatable. Den. 


\section{SOLANACEAE}

\section{Datura L.}

*D. ferox L.: "Fierce Thornapple". Weed of roadsides, waste places and river flats, thriving in moist situations. Unpalatable. Den.

D. inoxia Mill.: "Downy Thornapple". Collected from sandy rise near Balranald at western extremity of Riverine Plain. Common in this area. NSW.

*D. stramonium L.: "Common Thornapple". Widespread weed of waste places. Unpalatable. Den.

*D. wrightii Regel: "Hoary Thornapple". Weed of disturbed areas and waste places, roadsides and river flats. Unpalatable, but when eaten may poison stock. Den.

\section{Lycium L.}

*L. ferocissimum Miers: "African Boxthorn". Widespread plant found in almost every community, prevalent on sandy soil along fencelines and in proximity to areas of habitation. Den.

\section{Nicotiana L.}

*N. glauca Grah.: "Tree Tobacco". Common only in western districts, where it is found in flooded country and depressions. Unpalatable. Den.

Physalis L.

*P. sp. (probably angulata): Collected from sand hill near Barham, where common. Den.

*P. sp.: Collected from railway yards, Deniliquin. Den.

Several collections of Physalis spp. have been made in the DeniliquinFinley-Berrigan area but identification of specimens to species level has not been possible.

\section{Solanum L.}

*S. elaeagnifolium Cav.: "Silver-leaved Nightshade". Uncommon weed of cultivation in south eastern districts. Den.

S. ellipticum R. Br.: Recorded from Muggabah Creek, near Booligal. NSW.

S. esuriale Lindl.: "Quena". Widespread, common on loam soils, less common on clays and clay-loams. Relatively unpalatable. Den.

*S. nigrum L.: "Black-berry Nightshade". Widespread weed in moist situations and in areas of habitation. Unpalatable. Den.

S. rostratum Dun.: "Buffalo Burr". Collected from Hay, occasionally noted elsewhere in southern districts. NSW.

S. simile F. Muell.: “Oondoroo". Collected only from forest areas in southern districts. Den.

*S. triflorum Nutt.: "Three-flowered Nightshade". One collection only from channel bank near Mathoura. Den.

\section{SCROPHULARIACEAE}

Gratiola L.

G. pedunculata $\mathrm{R}$. Br.: One collection only, from loam soil in Millewa State Forest. Den. 
Kicksia Dumort.

*K. sieberi Dörfl.: "Hairy Toad-flax". One collection from Tuppal Creek area, south of Deniliquin. Common on loam soil in this locality. Den.

\section{Limosella $\mathrm{L}$.}

L. curdieana F. Muell.: "Large Mudwort". Widespread, locally common in damp or wet situations. Den.

L. australis R. Br.: "Mudwort". Widespread and common plant of mud and shallow water. Den.

\section{Mimulus L.}

M. gracilis R. Br.: "Slender Monkey-flower". Widespread, restricted to moist situations such as roadside drains and depressions. Den.

M. prostratus Benth.: "Small Monkey-flower". Localized occurrences on clay soil in saltbush community $64 \mathrm{~km}$ north of Balranald. Not recorded elsewhere. Den.

\section{Morgania R. Br.}

M. floribunda Benth.: "Blue Rod". Relatively common on loams and clay-loams in western districts, uncommon elsewhere. Unpalatable. Den.

\section{Parentucellia Viv.}

*P. latifolia (L.) Caruel: "Common Bartsia". Collected from clay soil $27 \mathrm{~km}$ east of Deniliquin, occasional occurrences elsewhere. Den.

\section{Verbascum L.}

*V. thapsus L.: "Great Mullein". One collection, from $24 \mathrm{~km}$ west of Narrandera. NSW.

*V. virgatum Stokes: "Twiggy Mullein". Weed of roadsides, river flats and waste places; more prevalent on sandy soils. Not common. Den.

\section{Veronica L.}

*V. peregrina L.: "Wandering Speedwell". Isolated occurrences on clay soil in Deniliquin area, also recorded from Hay and Barham districts. Den.

\section{MARTYNIACEAE}

\section{Proboscidea Keller}

*P. louisianica (Mill.) Thell.: "Purple-flowered Devil's Claw". A weed which is generally rare, but which may appear after summer rains. Unpalatable, with a large curved and barbed seed-capsule which may injure stock. Den.

\section{MYOPORACEAE}

Eremophila $\mathrm{R}$. Br.

E. divaricata (F. Muell.) F. Muell.: "Spreading Emu Bush". Recorded from Thule Creek in Barham district. NSW.

E. longifolia (R. Br.) F. Muell.: "Emu Bush". Widespread species, common in woodland and shrub communities on light soils. Palatable. Den. 
E. maculata (Ker-Gawl.) F. Muell.: "Fuchsia-bush". Generally common, restricted to the western fringes where it occurs on soils ranging from clays to loams. Relatively unpalatable, reputed to be poisonous to stock. Den.

\section{Myoporum Sol. ex Forst. f.}

M. debile (Andr.) R. Br.: Two collections only, from Eucalyptus largiflorens communities near Deniliquin. Den.

M. deserti A. Cunn. ex Benth.: "Dogwood". Widespread though rarely common, occurring as isolated plants on loam soils. Den.

M. montanum R. Br.: "Waterbush". Widespread shrub with occasional occurrence on sandhills and on sandy soils in vicinity of streams. Unpalatable. NSW.

M. platycarpum R. Br.: "Sugarwood". Widespread species occurring as occasional trees on sandy-loam soils. Den.

\section{PLANTAGINACEAE}

Plantago L.

*P. coronopus L. ssp. commutata (Guss.) Pilger: "Buck's-horn Plantain". Widespread, though more prevalent in southern districts, common only in years of high winter rainfall. Apparently restricted to loams and clay-loams. Den.

$P$. cunninghamii Decne.: Widespread, habitat unresolved. Previously confused with $P$. drummondii and $P$. turrifera, all three species mistakenly referred to as $P$. varia. NSW.

$P$. drummondii Decne.: Widespread and common in all communities. Abundant in moist situations. Palatable when young. NSW.

*P. lanceolata L.: "Ribwort", "Ribgrass". Weed occurring in and around areas of habitation. Not common. Den.

$P$. turrifera Briggs, Carolin et Pulley: Widespread and common in all communities. Abundant in small local depressions. Readily grazed when young. Den.

\section{RUBIACEAE}

Asperula L.

A. conferta Hook. f.: "Common Woodruff". Common in grasslands on clay and loam soils in the southern and eastern districts. Palatable. Den.

A. gemella Shaw et Turrill: "Twin-leaved Woodruff". One collection only from swamp area at "Ulonga", $48 \mathrm{~km}$ north-west of Hay. Common in this locality. Den.

\section{Galium L.}

*G. aparine L.: "Cleavers". Habitat appears to be damp, low-lying areas. Distribution unknown. Den.

\section{CUCURBITACEAE}

Citrullus Schrad. ex Eckl. et Zeyh.

*C. lanatus (Thunb.) Matsum. et Nakai: "Camel Melon". Widespread in disturbed areas, waste places and heavily grazed pastures. Generally restricted to light soils. Unpalatable. The fruits may be eaten in dry times and are suspected of being toxic to stock. Den. 
Cucumis L.

*C. myriocarpus Naud.: "Paddy Melon". Widespread on sands and loam soils. Prevalent weed of fallowed land. Unpalatable. Den.

\section{Ecballium A. Rich.}

*E. elaterium (L.) A. Rich.: "Squirting Cucumber". Specimens collected from fallowed paddocks near Berrigan. NSW.

\section{Zehneria Endl.}

Z. micrantha (F. Muell.) F. Muell.: Widespread, although uncommon. Found in areas following periodic inundation on most soil types. Unpalatable. Den.

\section{CAMPANULACEAE}

Pratia Gaudich.

P. concolor (R. Br.) Druce: “Poison Pratia". Widespread and common in damp, poorly drained situations. Reputedly poisonous to stock. Den.

P. darlingensis Wimmer: Recorded only from channel bank $48 \mathrm{~km}$ south of Deniliquin. Common in this locality and possibly overlooked elsewhere because of its small size. Den.

\section{Wahlenbergia Schrad.}

$W$. communis Carolin: "Tufted Bluebell". Widespread, prevalent in grasslands on loam and clay-loam soils. Palatable. Den.

W. fluminalis (J.M. Black) Wimmer ex Hj. Eichler: "River Bluebell". Restricted to the vicinity of streams, found on clays or sands but grows best on the silty soils of river flats. Palatable. Den.

$W$. stricta Sweet: "Tall Bluebell". Widespread and common in open woodlands and in grasslands on loam and clay-loam soils. Palatable. Den.

$W$. sp. aff. tadgellii Lothian: “Annual Bluebell”. Common in southern districts on loam soils. Palatable. Den.

\section{GOODENIACEAE}

Goodenia Sm.

G. glauca F. Muell.: "Pale Goodenia". Widespread and fairly common on clay and clay-loam soils in most communities. Palatable. Den.

G. gracilis R. Br.: "Slender Goodenia". Collected only from Millewa State Forest, south of Deniliquin. Den.

G. heteromera F. Muell.: "Spreading Goodenia". Widely distributed but uncommon. Found in depressions in woodlands and saltbush plains. Den.

G. pinnatifida Schlechtd.: "Cut-leaved Goodenia." Fairly common on clay and clay-loams throughout. Palatable. Den.

G. pusilliflora F. Muell.: "Small-flowered Goodenia". Widespread and abundant on clay and clay-loam soils. Palatable. Den.

G. subintegra F. Muell. ex Tate: "Silky Goodenia". Common on clay and clayloam soils in most communities. Very palatable. Den. 
ASTERACEAE ( = COMPOSITAE)

Acroptilon Cass.

*A. repens (L.) DC.: "Creeping Knapweed". Collected only from railway yards, Deniliquin. Den.

Actinobole Fenzl ex Endl.

A. uliginosum (A. Gray) $\mathrm{Hj}$. Eichler: "Flannel Cudweed". Occurs mainly in western and northern districts, where it may be common on sandy-loam soils, particularly after good winter-spring rains. Palatable. Den.

\section{Angianthus Wendl.}

A. brachypappus F. Muell.: "Spreading Cup-flower". Apparently restricted to sandy soils in northern districts, where it may be locally common in Maireana pyramidata communities. Den.

A. strictus (Steetz) Benth.: "Stiff Cup-flower". Widespread though never common, found on loam and clay-loam soils. Den.

\section{Arctotheca Wendl.}

*A. calendula (L.) Levyns (= Cryptostemma calendula (L.) Druce): "Cape-weed". Widespread weed, particularly common on light soils in southern districts. Fairly palatable and when eaten by dairy cows may taint the milk. Prolonged consumption of the plant may cause stock losses, due to the woolly seeds forming hair balls in the animal's stomach. Den.

Aster L.

*A. subulatus Michx.: "Aster Weed". Widespread and common on most soil types, particularly in damp, poorly drained situations. Unpalatable. Den.

\section{Brachycome Cass.}

B. basaltica F. Muell. var. gracilis Benth.: Widespread though uncommon, occurring in moist situations such as river flats and the borders of swamps. Den.

B. campylocarpa J.M. Black: Widespread and fairly common, particularly in northern and western districts, usually in moist situations such as local depressions. Palatable. Den.

B. curvicarpa G.L. Davis: Locally common on clay and clay-loam soils in southern districts. Den.

B. exilis Sond.: "Slender Daisy". One collection only from Maireana pyramidata community on sand ridge $80 \mathrm{~km}$ north-east of Hay. Common in this habitat. Den.

B. goniocarpa Sond. et F. Muell.: One collection only, from grey clay soil flood plain, $27 \mathrm{~km}$ east of Deniliquin, in which locality it was common. Den.

B. lineariloba (DC.) Druce: Widespread and common on clay and loam soils in most communities. Palatable. Den.

$B$. heterodonta DC. (=B. marginata Benth.): Widespread and locally common in grasslands on clay and clay-loam soils. Den.

B. papillosa G.L. Davis: Several records from south-eastern districts and from near Mossgiel. NSW. 
Calocephalus $\mathrm{R}$. Br.

C. citreus Less.: Occasionally common in woodlands in south-eastern districts. Den.

C. sonderi F. Muell.: "Yellow Poverty-weed". A common species found on clay and clay-loam soils in most communities. In years of good winter-spring rainfall dense populations of this aromatic annual may occur, to the detriment of other more useful species. Usually ignored by stock but may be eaten in the young stage in the absence of more palatable plants. Den.

\section{Calotis R. Br.}

C. cuneifolia $\mathrm{R}$. Br.: Common and widespread, apparently restricted to sandy-loam soils. Grazed at times but not regarded as a useful species. In common with most Calotis species, its spined fruits may be a nuisance in the fleeces of sheep. Den.

C. erinacea Steetz: "Tangled Burr-daisy". Widespread but not common. Confined to sandy soils. Relatively unpalatable, with spiny fruits. Den.

C. hispidula (F. Muell.) F. Muell.: "Hairy Burr-daisy". Also known as "Bogan Flea". Widespread and very common in all communities. Relatively unpalatable, with objectionable spiny burrs. Den.

C. scabiosifolia Sond. et F. Muell.: "Rough Burr-daisy". Widespread and locally common on clay and clay-loam soils. Relatively unpalatable, though eaten at times. Den.

C. scapigera Hook.: "Tufted Burr-daisy". Widespread though common only in localized areas along the banks of streams and swamps, occasionally in depressions on the saltbush plains. Relatively unpalatable. Den.

\section{Carduus L.}

*C. pycnocephalus L.: "Slender Thistle". Common on river flats and in well watered areas such as roadside drains and irrigated pastures. Rarely grazed. Den.

*C. tenuiflorus Curt.: "Slender Thistle". Recorded from Deniliquin and Hay districts. NSW.

\section{Carthamus L.}

*C. lanatus L.: "Saffron Thistle". Widespread, very common in southern and eastern districts. More prevalent on self-mulching clay-loam soils but will grow on a wide range of soil types. Unpalatable, though young plants may be eaten in times of feed shortage. A weed with rigid spiny leaves. Den.

\section{Cassinia R. Br.}

C. arcuata $\mathrm{R}$. Br.: "Chinese-shrub". Confined to the southern districts where it may occur as scattered plants in open woodlands and forests. Den.

\section{Centaurea L.}

*C. calcitrapa L.: "Star Thistle". May be locally common, particularly in southern and eastern districts. A useless spiny weed which may form dense tangled thickets. Den.

*C. melitensis L.: "Maltese Cockspur". Widespread and common in practically all communities on a wide range of soils. Palatable, particularly in the young stage. Den. 
Centipeda Lour.

C. cunninghamii (DC.) A. Br. et Aschers.: "Common Sneezeweed". Widespread throughout in depressions, gilgais and swamps. Generally regarded as unpalatable. Used by aboriginals to produce a "medical" brew said to cure all ills. Den.

C. thespidioides F. Muell.: "Desert Sneezeweed". Found in similar situations as $C$. cunninghamii but is always less common. Unpalatable, though eaten at times, particularly in western areas. Den.

\section{Chondrilla $\mathbf{L}$.}

*C. juncea L.: "Skeleton-weed". An introduced weed which has rapidly invaded crop lands and, to a lesser degree, native pastures on loam and sandy soils in southern and eastern districts. Palatable, and in some areas regarded as a useful forage, however its aggressiveness and its tangled growth in crops outweigh any advantages it may have. Den.

\section{Cichorium L.}

*C. intybus L.: "Chicory". An occasional weed of roadsides and waste places in southern districts. Unpalatable. Den.

\section{Cirsium Mill.}

${ }^{*}$ C. vulgare (Savi) Ten.: "Spear Thistle". Widespread weed common in moist situations such as roadside drains and irrigated pastures. Grazed only in times of severe stress. Den.

\section{Cotula L.}

*C. australis (Sieb. ex Spreng.) Hook. f.: "Common Cotula". Apparently confined to well watered situations in areas of habitation and along roadsides in southern districts. Den.

*C. bipinnata Thunb.: "Cotula". Widespread, common in damp situations in most communities. Relatively unpalatable. Den.

C. coronopifolia L.: "Waterbuttons". Recorded from irrigation channel near Caldwell and from swamp near Wanganella. NSW.

\section{Conyza Less.}

*C. bonariensis (L.) Cronquist: "Flax-leaf Fleabane". Usually a weed of waste places and disturbed areas, occasionally occurring in natural pasture and on river flats. Unpalatable. Den.

*C. floribunda Kunth: "Tall Fleabane". Collected from river flat near Deniliquin but probably overlooked elsewhere because of its similarity to $C$. bonariensis. Den.

\section{Craspedia Forst. f.}

C. chrysantha (Schlechtd.) Benth.: "Golden Billy-buttons". Widespread, common throughout, particularly on clay-loams in saltbush plains and open woodland communities. Moderately palatable when young. Den.

C. globosa (Benth.) Benth.: "Drumsticks". Generally confined to depressions on clay-loam soils in southern districts, where it may be locally common. Unpalatable. Den. 
C. pleiocephala F. Muell.: "Soft Billy-buttons". Occurs mainly in western and northern districts, where it may be common in years of high winter-spring rainfall. Moderately palatable. Den.

C. uniflora Forst. f. sens. lat.: "Common Billy-buttons". Occasional occurrences in depressions in southern districts. Unpalatable. Den.

C. sp. Apparently unnamed species collected from near Mossgiel. Den.

\section{Cymbonotus Cass.}

C. preissianus Steetz: “Bear's Ear”. Distribution apparently restricted to forests and woodlands bordering streams in southern districts. Not common. Den.

\section{Eclipta L.}

E. platyglossa F. Muell.: "Yellow Twin-heads". Confined to damp situations in southern districts where it may be common in localized areas. Apparently palatable but of little value because of its limited occurrence. Den.

\section{Epaltes Cass.}

E. australis Less.: "Spreading Nut-heads". One collection from Black Swamp near Wanganella. Den.

E. cunninghamii (Hook.) Benth.: "Tall Nut-heads". Recorded from swampy areas in the western Riverine Plain, also from "Zara", Wanganella. NSW.

Eriochlamys Sond. et F. Muell. ex Sond.

E. behrii Sond. et F. Muell. ex Sond.: "Woolly Mantle". Common in grasslands and open woodlands in the southern districts. Aromatic annual which is extremely unpalatable. Den.

\section{Gnaphalium L.}

G. gymnocephalum DC.: "Japanese Cudweed". Widespread, more common in southern and eastern districts in grasslands, open woodlands and saltbush plains. Moderately palatable but of little importance. Den.

It is probable that the similar $G$. sphaericum Willd. also occurs in similar habitats but has been overlooked.

G. luteoalbum L.: "Jersey Cudweed". Fairly common in areas of habitation and irrigation, rare in natural pastures in dry areas. Generally restricted to loam and sandy-loam soils. Palatable, but of little value. Den.

*G. spicatum Lamk.: "Cudweed". One collection, from river flat near Deniliquin. Den.

\section{Hedypnois Mill.}

*H. rhagadioloides (L.) Willd. ssp. cretica (L.) Hayek (= Hedypnois cretica (L.) Willd.): "Cretan-weed". Widespread, common only in grasslands, open woodlands and occasionally on saltbush plains. Habitat mainly restricted to clay-loams and clays. Very palatable, particularly when young. Den.

\section{Helichrysum Mill.}

H. apiculatum (Labill.) D. Don: "Yellow Buttons". Widespread, but much more common in grasslands and open woodlands in southern districts, occurring mainly on clay-loam and loam soils. Palatable. Den. 
H. bracteatum (Vent.) Andr. sens. lat.: "Orange Paper-daisy". Widespread, though more frequent in northern districts, where it may be locally common. Usually occurs on sandy-loams but may be found on most soil types. Unpalatable. Den.

H. rutidolepis DC.: Collected from two sites along river bank near Deniliquin - possibly occurs in similar situations elsewhere. Den.

H. semipapposum (Labill.) DC.: Widespread, may be locally common on sands and sandy-loams. Unpalatable. Den.

\section{Helipterum DC.}

$H$. australe (A. Gray) Druce: "Urn Paper-daisy". Common in years of good winter-spring rains on loam and clay soils in southern and eastern districts. Palatable but of minor importance. Den.

H. corymbiflorum Schlechtd.: "Small White Paper-daisy". Widespread and very common in most communities after good winter-spring rains. More prevalent on clays but may be found on most soil types. Rarely grazed. Den.

H. floribundum DC.: "Large White Paper-daisy". Widespread, though more common in northern and western districts where it may be the dominant annual after good winter-spring rains. Unpalatable, but dry standing material may be utilized when other forage is unavailable. Den.

A. hyalospermum F. Muell. ex Benth. (=H. variabile Ostenf.): "Yellow Paperdaisy". Common in grasslands and open woodlands of southern districts, occurring on both clay and loam soils. Palatable, but rarely present in any quantity. Den.

H. jessenii F. Muell.: “Orange Sunray". Distribution apparently restricted to the drier northern districts, where it occurs on clay-loam and loam soils, though rarely common. Apparently unpalatable. Den.

H. molle (A. Cunn. ex DC.) Wilson: "Golden Paper-daisy". Widespread and common on a wide range of soils, usually more abundant on clays and clayloams. Regarded as useful forage. Den.

H. moschatum (A. Cunn. ex DC.) Benth.: "Musk Sunray". Common in northern and western districts, occasional elsewhere, usually on loam and sandy-loam soils. Moderately palatable. Den.

H. polygalifolium DC.: Widespread though rarely common. Occurs on a wide range of soils, more prevalent on loams and sandy-loams. Moderately palatable. Den.

H. pygmaeum (DC.) Benth.: "Pigmy Paper-daisy". Widespread annual which may be very common on clay and clay-loam soils following good winter-spring rains. Palatable and a useful species when occurring in quantity. Den.

\section{Hypochoeris $\mathbf{L}$.}

*H. glabra L.: "Smooth Catsear". Widespread and common on all soil types, attaining maximum size on sands and sandy-loams. May be a weed in irrigated pastures and lawns but is very palatable and forms a useful spring forage in natural pastures. Den.

*H. radicata L.: "Catsear". Probably less common than $H$. glabra. Both species have similar habitats and pastoral value. Den. 
Inula $\mathrm{L}$.

*I. graveolens (L.) Desf.: "Stinkwort". Widespread and common weed of roadsides, river flats, moist depressions, waste places and fallows. Unpalatable, but occasionally eaten in the absence of other forage. When eaten it taints meat and dairy products. Stock losses may occur due to the embedding of fine seed hairs in the bowel, allowing entry of bacteria which produce poisonous toxins. Den.

\section{Isoetopsis Turcz.}

I. graminifolia Turcz.: "Grass Cushions". Widespread and relatively common after good winter-spring rains. Occurs on most soil types. Palatable but rarely contributes significantly to the pasture as a whole. Den.

\section{Ixiolaena Benth.}

I. leptolepis (DC.) Benth.: "Stalked Ixiolaena". Widespread and common in most communities. Relatively unpalatable, but grazed at times. Den.

\section{Lactuca L.}

*L. saligna L.: "Wild Lettuce". Recorded from "Zara", Wanganella, 1913. NSW.

*L. serriola L.: "Prickly Lettuce". Widespread weed found on most soil types in favoured situations such as river flats, fallows, old cultivation areas and gardens. Grazed to some extent when young. Den.

\section{Leptorhynchos Less.}

L. panaetioides (DC.) Benth.: "Woolly Buttons". Widespread and common, particularly on clay and clay-loam soils in grasslands and on the saltbush plains. Relatively unpalatable but grazed at times. Den.

L. squamatus (Labill.) Less.: Widespread but rarely common, usually on clay-loam soils. Den.

\section{Microseris D. Don}

M. scapigera (Sol. ex A. Cunn.) Sch.-Bip.: "Yam". May be locally common in leniently grazed grassland and saltbush pastures on both clay and loam soils in southern and central districts. Apparently very palatable. Den.

\section{Millotia Cass.}

M. myosotidifolia (Benth.) Steetz: Collected from only the one locality, $32 \mathrm{~km}$ west west of Narrandera, where this species was common on sandy-loam soil beneath Callitris columellaris. Den.

\section{Minuria DC.}

M. cunninghamii (DC.) Benth.: "Bush Minuria". Widespread, may be common in saltbush communities, usually growing in the protection of the shrubs. Heavily utilized where accessible. Den.

M. denticulata (DC.) Benth.: "Woolly Minuria". Widespread, rarely abundant except in roadside drains and in depressions on the saltbush plains. Moderately palatable. Den.

M. integerrima (DC.) Benth.: "Smooth Minuria". Occurrence and palatability similar to that of $M$. denticulata. Den.

M. leptophylla DC.: "Minnie Daisy". Widespread, may be locally common on light soils in grassland communities. Moderately palatable. Den. 
Myriocephalus Benth.

M. rhizocephalus (DC.) Benth.: "Woolly-heads". Widespread, common in years of high winter-spring rainfall, usually occurring in shallow local depressions on loam and clay-loam soil. Grazed, but unimportant because of its small size. Den.

Olearia Moench

o. pimeleoides (DC.) Benth.: "Pimelea Daisy-bush". Recorded from "Zara", Wanganella, 1903. NSW.

\section{Onopordum L.}

*O. acaulon L.: "Stemless Thistle". Prevalent along roadsides and in natural pastures in western districts, also occurs in irrigated pastures. A useless weed. Den.

Picris L.

*P. echioides L.: "Ox-tongue". Weed of roadsides and pastures in southern districts, where it may be locally common. A bristly plant which is rarely grazed. Den.

*P. hieracioides L.: "Hawkweed". Occasional occurrence in sandy situations, such as river flats, in southern districts; elsewhere rare. Den.

Podolepis Labill.

P. canescens A. Cunn. ex DC.: "Grey Podolepis". Recorded from Wanganella, 1903. NSW.

P. muelleri (Sond.) G.L. Davis: "Podolepis". Widespread and common throughout Bladder Saltbush communities, particularly in years of high winter-spring rainfall. More prevalent on clay-loam soils. Relatively unpalatable. Den.

\section{Podospermum DC.}

*P. resedifolium (L.) DC. (= $P$. calcitrapifolium DC.; Scorzonera calcitrapifolia Vahl): Locally common in good years on grasslands in southern districts. Usually found on clay soils. Palatable. Den.

\section{Scolymus L.}

*S. hispanicus L.: "Golden Thistle". Localized infestation of grassland $30 \mathrm{~km}$ south of Deniliquin only known occurrence. Den.

\section{Schkuhria Roth.}

*S. pinnata (Lam.) Kuntze ex Cabrera: “Dwarf Marigold”. Collected from roadside near Conargo, occasional occurrences elsewhere in southern districts. Den.

\section{Senecio L.}

S. cunninghamii DC.: "Branching Groundsel". Widespread, locally common on flats and depressions along creeks and rivers. Relatively unpalatable, though browsed at times. Den.

S. glossanthus (Sond.) Belcher: "Slender Groundsel". Widespread and relatively common on the saltbush plains, less common in open woodlands and grasslands. Found on soils ranging from clays to loams. Palatable and suspected of being poisonous to stock but rarely occurs in sufficient quantity alone to cause trouble. Den. 
S. platylepis DC.: "Toothed Groundsel". Widespread though never common, usually occurring as isolated plants in roadside drains. Den.

S. quadridentatus Labill.: "Cotton Fireweed". Widespread and relatively common in River Red Gum forests and open woodlands, rare in grasslands and saltbush communities. More prevalent on sandy or silty soils. Rarely grazed. Den.

S. runcinifolius J.H. Willis: "Tall Groundsel". Widespread, rarely common except in shrub communities where it is protected by low dense shrubs such as Nitraria billardieri. Palatable, suspected of poisoning stock, but unlikely to do so because it rarely occurs in sufficient quantity. Den.

\section{Silybum Adans.}

*S. marianum (L.) Gaertn.: "Variegated Thistle". Widespread in moist situationis such as roadside drains, river flats and irrigation areas, usually as localized dense patches, rarely extending over large areas. Moderately palatable when young, considered to be poisonous at times. Den.

\section{Sonchus L.}

*S. asper (L.) Hill: "Rough Sowthistle". Widespread, though rarely abundant, in fallows and gardens and moist situations in grassland, open woodland and saltbush communities. Grazed when young. Den.

*S. oleraceus L.: "Common Sowthistle". Widespread and relatively common in most communities on all soil types after good winter-spring rains. Always heavily grazed. Den.

\section{Stuartina Sond.}

S. muelleri Sond.: "Spoon Cudweed". Widespread on light soils, rarely conspicuous except in years of good winter-spring rainfall. Den.

\section{Taraxacum Wiggers}

*T. officinale Weber ex Wiggers: "Dandelion". Occurrence restricted to gardens and areas of habitation, extending occasionally to moist situations such as river flats. Den.

\section{Toxanthes Turcz.}

T. perpusillus Turcz.: Collected from loam soil during wet winter-spring. Apparently occurs over wide range in good seasons but is overlooked because of its size. Den.

\section{Vittadinia A. Rich.}

V. triloba (Gaudich.) DC. sens. lat.: "Fuzzweed". Widespread and relatively common though rarely abundant. Usually occurs on lighter types of soils. Moderately palatable. Den.

\section{Xanthium L.}

* $X$. occidentale Bertol.: "Noogoora Burr". Widespread, locally common in moist situations such as river and creek flats and to a lesser degree, roadside drains. This species has increased markedly in the Riverine Plain in recent years. Unpalatable, poisonous when young, with spiny burrs which contaminate wool. Den.

* $X$. spinosum L.: "Bathurst Burr". Widespread and common on all soil types, particularly after summer rains. Suspected of being poisonous to stock but because of its long spines it is rarely eaten. The burrs are a serious contaminant of wool. Den. 


\section{ADDENDUM}

( added in proof)

POACEAE

Astrebla F. Muell.

A. lappacea (Lindl.) Domin: "Curly Mitchell Grass". Occurs on clay soil plains of the northern Riverine Plain, particularly around Conoble, where it may cover extensive areas after favourable summer rains. Good forage when green but little nutritive value is retained after drying. Den.

\section{CYPERACEAE}

Eleocharis R. Br.

E. sphacelata R. Br.: “Tall Spike Rush". A common species on intermittently flooded country along the Murrumbidgee River in western regions. Regarded as useful feed for cattle. Den.

\section{CHENOPODIACEAE}

\section{Chenopodium L.}

C. auricomum Lindl.: "Golden Goosefoot". Restricted to the northern Riverine Plain where isolated plants occur in low-lying areas on clay soil. A useful forage species, particularly during drought periods. Den.

\section{CAESALPINIACEAE}

\section{Cassia L.}

C. circinnata Benth.: One collection from near Coleambally. Den.

C. barclayana Sweet var. barclayana: Collected from roadside $6 \mathrm{~km}$ north-east of Hay. Occasional plants noted in similar situations in southern and eastern districts. Den.

APIACEAE

Foeniculum (Tourn.) L.

F. vulgare Mill.: "Fennel". Widely distributed weed of roadsides and waste places. Den. 
$\because \cdots$ 


\section{INDEX}

\begin{tabular}{l} 
Abutilon \\
Acacia \\
Acacia, Gold-dust \\
$\quad$, Streaked \\
\multicolumn{1}{c}{ Mallee } \\
Acetosa \\
Acetosella \\
Acroptilon \\
Actinobole \\
Agropyron \\
Agrostis \\
Aira \\
Aizoaceae \\
Ajuga \\
Alhagi \\
Alismataceae \\
Alopecurus \\
Alternanthera \\
Alyssum
\end{tabular}

Amaranthaceae

Amaranth, Green , Slim

Amaranthus

Amaryllidaceae

Ammania

Amphibromus

Amsinckia

Amyema

Anagallis

Angianthus

Anguillaria

Aphanes

Apiaceae

Arabian Grass

Arabidella

Arctotheca

Aristida

Arthropodium

Asparagus

Asparagus

Asperula

Asphodelus

Aster

Asteraceae

Aster Weed

Atriplex

Avena

Azolla

Azolla, Red

Azollaceae

Babbagia

Babbagia

Barley Grass, , Sea

Barnyard Grass

Bartsia, Common

\section{4}

259

259

259

248

248

275

275

235

235

235

254

270

260

235

236

253

256

253

253

253

253

246

266

236

269

247

267

275

245

259

268

242

256

275

236

245

245

245

273

245

275

275

275

249

236

234

234

234

250

250

239

239

238

272
Bassia

Beard Grass, Annual

Bear's Ear

250

241

Beetle Grass, Brown

238

246

Bent Grass, Reed 237

Berrigan 258

Billy-buttons, Common 278

, Golden 277

, Soft 278

Bindweed, Australian 268

Blackberry $\quad 259$

Blackthorn, Australian 258

Bladder Ketmia 265

Blown Grass 235

Bluebell, Annual 274

, River 274

, Tall 274

, Tufted 274

Bluebush, Black 252

$\begin{array}{ll}\text {, Pearl } & 252 \\ \text { Short-leaved } & 251 \\ \text { il } & 268 \\ & 241\end{array}$

$\begin{array}{ll}\text {, Pearl } & 252 \\ \text { Short-leaved } & 251 \\ & 268 \\ \text { Ss, Kentucky } & 241\end{array}$

$\begin{array}{ll} & \text {, Pearl } \\ \text {, Short-leaved } & 252 \\ \text { Blue Devil } & 251 \\ \text { Blue Grass, Kentucky } & 268 \\ \text { Blue Rod } & 241\end{array}$

$\begin{array}{ll}\text { Blue Grass, Kentucky } & 241 \\ \text { Blue Rod } & 272\end{array}$

Boerhavia 253

Bogan Flea 276

Boraginaceae 269

Boree 260

Bothriochloa 236

Bottle-brush, Prickly 266

Bottle-washers 238

Box, Black 266

, Black Mallee 267

, Inland Grey 266

, Yellow 266

Boxthorn, African 271

Brachycome 275

Bracken, Austral 234

Brassica 256

Brassicaceae 256

Bristle Grass, Rough 242

Briza , Tiny 236

Brome, Curly 236

$\begin{array}{ll}\text {, Great } & 236 \\ \text {, Red } & 236 \\ \text {, Sand } & 236 \\ \text {, Soft } & 236 \\ \text { m S } & 236 \\ \text { mbush, Desert } & 262\end{array}$

$\begin{array}{ll}\text {, Great } & 236 \\ \text {, Red } & 236 \\ \text {, Sand } & 236 \\ \text {, Soft } & 236 \\ \text { is } & 236 \\ \text { mbush, Desert } & 262\end{array}$

$\begin{array}{ll}\text {, Great } & 236 \\ \text {, Red } & 236 \\ \text {, Sand } & 236 \\ \text {, Soft } & 236 \\ \text { is } & 236 \\ \text { mbush, Desert } & 262\end{array}$

$\begin{array}{ll}\text {, Great } & 236 \\ \text {, Red } & 236 \\ \text {, Sand } & 236 \\ \text {, Soft } & 236 \\ \text { is } & 236 \\ \text { mbush, Desert } & 262\end{array}$

$\begin{array}{cc}\text {, Great } & 236 \\ \text {, Red } & 236 \\ \text {, Sand } & 236 \\ \text {, Soft } & 236 \\ \text { Bromis } & 236 \\ \text { Broombush, Desert } & 262\end{array}$

$\begin{array}{ll}\text { Broombush, Desert } & 262 \\ \text { Broughton Pea } & 261\end{array}$

Buchan Weed 257

Buckbush 252

Bugle, Australian 270

Bugloss, Wild 269 
Buglossoides

Bulbine = Bulbinopsis

Bulbinopsis

Bull Oak

Bullock-bush

Burr, Bathurst

, Buffalo

, Copper

, Galvanized

, Goathead

, Grey Copper

, Noogoora

Burr-daisy, Hairy

$$
\begin{aligned}
& \text {, Rough } \\
& \text {, Tangled } \\
& \text {, Tufted }
\end{aligned}
$$

Burr Grass, Small

$$
\text { , Spiny }
$$

Burr Stickseed

Burr-weed, Yellow

Bursaria

Buttercup, River

Button Grass Smooth

Buttons, Woolly , Yellow

Caesalpiniaceae

Caladenia

Calandrinia

Callistemon.

Callitrichaceae

Callitriche

Callitris

Calocephalus

Calostemma

Calotis

Caltrops

Calytrix

Camel Thorn

Campanulaceae

Canary Grass, Lesser

Cane Grass,

Cannabaceae , Umbrella

Cannabis

Cape-weed

Capsella

Cardaria

Carduus

Carex

Carrot, Australian

Carpet-weed, Hairy

Carthamus

Caryophyllaceae

Cassia

Cassia, Desert
269

245

245

246

264

282

271

250

250

250

250

282

276

276

276

276

242

236

269

269

258

256

256

256

237

280

278

260

246

254

266

264

264

234

276

246

276

263

266

260

274

241

238

240

246

246

275

256

257

276

243

268

254

276

255

260

260
Cassinia

Casuarina

Casuarinaceae

Catchfly

Cat-head

Catsear,

, Smooth

Catstail, Annual

Caustic Weed

Cenchrus

Centaurea

Centaurium

Centaury, Australian

Centipeda

Cerastium

Chariot Wheels

Chenopodiaceae

Chenopodium

Cherry, Jointed

Chicory Slender

Chickweed,

$$
\text { , Mouse-ear }
$$

Chinese Lantern,

Chinese-shrub , Swamp

Chloris

Chocolate Lily, Nodding

Chondrilla

Cichorium

Cirsium

Citrullus

Cleavers

Clematis

Clematis, Narrow-leaved

Clover, Clustered

, Cooper

, Drooping-flowered

, Haresfoot

, Hop

, Narrow-leaved

, Woolly

Cockspur, Maltese

Compositae $=$ Asteraceae

Convolvulaceae

Convolvulus

Conyza

Cooba,

, River

Corn Gromwell

Coronopus

Cotton Bush,

$$
\text { , Black }
$$

, Eastern

Cotton Grass

Cotula

Cotula,

, Common
276

246

246

255

263

279

279

240

264

236

276

267

267

277

255

251

249

251

247

247

277

255

255

264

264

276

237

245

277

277

277

273

273

255

255

262

262

262

262

262

262

262

276

275

267

267

277

260

260

269

257

251

251

252

237

277

277

277 
Couch,

$$
\begin{aligned}
& \text {, Rat's-tail } \\
& \text { Water }
\end{aligned}
$$

Craspedia

Crassula

Crassulaceae

Cress, Earth

, Hairy

, Hoary

, Yellow

Cressa

Cretan-weed

Crowfoot, Blue

$$
\text { , Common }
$$

Cruciferae $=$ Brassicaceae

Cryptostemma $=$ Arctotheca

Cucumber, Squirting

Cucumis

Cucurbitaceae

Cudweed,

$$
\begin{aligned}
& \text {, Flannel } \\
& \text { Japanese } \\
& \text {, Jersey } \\
& \text {, Spoon }
\end{aligned}
$$

Cumbungi

Cup-flower, Spreading , Stiff

Cupressaceae

Cushions, Grass

Cymbonotus

Cymbopogon

Cynodon

Cynoglossum

Cyperaceae

Cyperus

Cypress Pine, Murray

$$
\text { , White }
$$

Dactyloctenium

Daisy, Slender

$$
\text { , Minnie }
$$

Daisy-bush, Pimelea

Damasonium

Dandelion

Danthonia

Datura

Daucus

Dennstaedtiaceae

Devil's Claw, Purple-flowered

Deyeuxia

Dianella

Dichelachne

Dichondra

Dichopogon

Digitaria

Dillon Busb

Diplachne
275

278

278

282

234

275

275

234

280

278

234

237

269

243

243

234

234

237

275

280

281

235

282

237

271

268

234

272

237
Diplotaxis

257

Dirty Dora

Disphyma

243

Diuris

254

Dock, Bladder

, Clustered

, Curled

, Pink

, Shiny

, Swamp

, Wiry

Dodonaea

Dog Rose

Dogwood

Double Gee

Drumsticks

Duckweed

Early Nancy

Ecballium

Echinochloa

Echium

Eclipta

Ehrharta

Elatinaceae

Elatine

Eleocharis

Elodea

Elodea

Emex

Emex, Spiny

Emu Bush,

Enchylaená

, Spreading

Enneapogon

Epaltes

Epilobium

Eragrostis

Eremophila

Erigeron = Conyza

Eriochlamys

Eriochloa

Erodium

Eryngium

Eucalyptus

Eulalia

Euphorbia

Euphorbiaceae

Eutaxia

Eutaxia

Exocarpos

Fabaceae

Fairy Grass

Fairy Spectacles

Fat Hen

Feather Grass, Long-styled

Fescue, Rat's-tail 
Fimbristylis

Fissure Weed, Bottle , Slender

Fireweed, Cotton

Five-minute Grass

Flax, Wild

Flax-lily, Pale

Fleabane, Flax-leaf , Tall

Flinders Grass

Fog-fruit

Forget-me-not, Hairy

Four-leaf All-seed

Foxtail, Marsh

Frankenia

Frankeniaceae

Fringe-lily, Twining

Fringe-myrtle, Common

Fringe-rush, Common

Fuchsia-bush

Fumaria

Fumariaceae

Fumitory, Dense

Fuzzweed

Galium

Galenia

Gall-weed

Gasoul = Mesembryanthemum

Geijera

Gentianaceae

Geococcus

Geraniaceae

Geranium

Germander, Grey

Glasswort

Glinus

Glyceria

Glycine

Glycine, Twining

Glycyrrhiza

Gnaphalium

Golden Moths

Golden-top

Goodenia

Goodenia, Cut-leaved

, Pale

, Silky

, Slender

, Small-flowered

Goodeniaceae

, Spreading

Goosefoot, Keeled

$$
\text { , Nettle-leaved }
$$

, Nitre

, Purple

Gramineae $=$ Poaceae

Gratiola
Groundsel, Branching 281

$$
\text { , Slender }
$$$$
\text { , Tall }
$$$$
\text { , Toothed }
$$

281

282

Gum, River Red

282

266

266

Hair Grass, False $\quad 241$

, Silvery 235

Hakea 247

Haloragaceae $\quad 267$

Haloragis $\quad 267$

Harmsiodoxa 257

Hawkweed 281

Hedypnois 278

Helichrysum 278

Heliotrope 269

Heliotropium $\quad 269$

Helipterum 279

Hemp 246

Heterodendrum 264

Hexham Scent 261

Hibiscus 265

Hirschfeldia $\quad 257$

Holcus 239

Hollyhock, Australian 265

Hop-bush, Narrow-leaved 264

Hordeum , Wedge-leaved 239

Horehound 270

Hound's Tongue, Australian $\quad 269$

Hydrocharitaceae , Sweet

Hydrocotyle $\quad 267$

Hypericaceae 265

Hypericum 265

Hypochoeris 279

Hypoxidaceae 246

Hypoxis 246

Ice-plant 254

Indigo Bush 251

Inula 280

Iridaceae 246

Iseilema 239

Isoetopsis 280

Ixiolaena $\quad 280$

Ixiolaena, Stalked 280

Jasmine, Desert 267

Jasminum 267

Jerry-jerry 266

Joyweed, Lesser 253

Juncaceae 244

Juncaginaceae 235

Juncus 244

Kangaroo Grass 242

Khaki Weed 253 
Kidney-weed

Kicksia

Knapweed, Creeping

Knotweed, Creeping

, Pale

, Slender

, Small

Kochia $=$ Maireana

Koeleria

Labiatae $=$ Lamiaceae

Lactuca

Lamarckia

Lamb Tails

Lamiaceae

Lavatera

Leek, Native

Lemnaceae

Lepidium

Leptochloa

Leptorhynchos

Lettuce, Prickly , Wild

Lignum,

Liliaceae , Slender

Lily, Leek , Swamp , Wilcannia

Limosella

Linaceae

Linum

Lipocarpha

Lolium

Lomandra

London Rocket

Loosestrife, Hyssop

Loranthaceae , Purple

Lotus

Love Grass, African

, Brown's

, Clustered

, Mallee

, Purple

Ludwigia

, Weeping

Lycium

Lycopsis

Lysiana

Lythraceae

Lythrum

Maireana

Malacocera

Mallee, Congoo

$$
\text { , Red }
$$

Mallow, Red-flowered , Small-flowered
Malva $\quad 265$

Malvaceae $\quad 264$

Marigold, Dwarf 281

Marrubium $\quad 270$

Marsh Grass $\quad 242$

Marshwort, Wavy $\quad 267$

Marsilea $\quad 234$

Marsileaceae 234

Martyniaceae $\quad 272$

Mat-rush, Many-flowered 246 , Scented 245 Woolly $\quad 245$

Meadow Grass, Water 239

Medicago $\quad 261$

Medic, Barrel 261 , Burr $\quad 261$

, Cut-leaved 261

, Small-leaved 261

Melaleuca Woolly Burr $\quad 261$

Melilotus $\quad \therefore \quad 261$

Melon, Camel 273

, Paddy 274

Menkea $\quad 257$

Mentha $\quad 270$

Menyanthaceae $\quad 268$

Mesembryanthemum 254

Mesquite $\quad 261$

Microtis 246

Microseris 280

Mignonette, Wild 258

Miljee $\quad 259$

Millet, Native 240

Millotia Rice

Millotia

Mimulus 272

Mint, River $\quad 270$ , Slender 270

Minuria 280

Minuria, Bush 280 , Smooth 280 ,Woolly 280

Mistletoe, 247

$\begin{array}{ll}\text {, Grey } & 247\end{array}$

Modiola 265

Monkey-flower, Slender $\quad 272$

, Small 272

Moonah 267

Morgania $\quad 272$

Mouse-tail 255

Mud Grass, Spiny 241

Mudwort, 272

272

Muehlenbeckia 248

Mulga 259

Mullein, Great $\quad 272$

272 
Mustard, Indian Hedge 258

Myall , Smooth

Myoporaceae

Myoporum

Myosurus

Myriocephalus

Myriophyllum

Myrtaceae

Nardoo,

Native Leek

$$
\text { Narrow-leaved }
$$

Native Liquorice

Needle Grass

Needlewood

Neelie

Nettle, Small

Neverfail Grass

New Zealand Spinach

Nicotiana

Nigger-heads

Nitraria

Nitre-bush

Nightshade, Black-berry

$$
\text { , Silver-leaved }
$$

, Three-flowered

Nut-grass, Downs

Nut-heads, Tall

Nymphoides

$$
\text { Spreading }
$$

Oat, Wild

Oenothera

Oleaceae

Olearia

Omphalolappula

Onagraceae

Onion Grass, Small-flowered

Onion-orchid, Common

Onion Weed

Onopordum

Oondooroo

Orchidaceae

Oryzopsis

Ottelia

Oxalidaceae

Oxalis

Oxalis, Yellow

Ox-tongue

Pachycornia

Papaver

Papaveraceae

Panic, Hairy

$$
\text { , Rigid }
$$

Panic Grass, Finger

Panicum
Paper-daisy, Golden

$$
\text { , Large White }
$$$$
\text { , Orange }
$$$$
\text { , Pigmy }
$$

, Small White

, Urn

, Yellow

Papilionaceae $=$ Fabaceae

Paradoxa Grass

Parapholis

Parentucellia

Parietaria

Paspalidium

Paspalum

Paspalum

Paterson's Curse

Pellitory, Forest

Pennisetum

Pennyroyal,

Pennywort, Native

Pentaschistis

Peppercress,

$$
\text { , Bundled }
$$

Pepper Grass

Petrorhagia

Phalaris

Phalaris

Phlegmatospermum

Phragmites

Phyla

Phyllanthus

Physalis

Pigeon Grass, Whorled

Picris

Pigface

Pigweed

Pimelea

Pink, Velvet

Pittosporaceae

Pittosporum

Plains Grass

Plagiobothrys

Plantaginaceae

Plantago

Plantain, Buck's-horn

Plume Grass, Short-haired

Poa

Poa, Annual , Bulbous

Poaceae

Podolepis

Podolepis,

Podospermum

Polycarpon

Polygonaceae
279

279

279

279

279

279

279

260

241

240

272

247

240

240

240

269

247

241

270

270

267

241

257

257

257

240

255

241

241

257

241

270

264

271

242

281

254

255

260

255

258

258

242

270

273

273

273

237

241

241

241

235

281

281

281

281

255

248 
Polygonum

248

Rubiaceae

273

Polypogon

241

Rubus

259

Pondweed, Floating

235

Poppy, Rough

Rumex

249

Portulaca

Rush, Sharp

244

255

Portulacaceae

, Toad

244

254

Potamogetonaceae

, Giant

244

Rush-lily, Yellow 245

Poterium

235

Poverty-weed, Yellow

Rutaceae

263

276

Prairie Grass

Ryegrass, Curly

240

236

Pratia

, Perennial

240

274

Pratia, Poison

, Wimmera

240

Primrose, Common Evening

$$
\text { , Evening }
$$

Primulaceae , Water

Sage, Wild

270

267

267

Proboscidea

272

Prosopis

261

Proteaceae

247

Pseudoraphis

241

Psoralea

261

Pteridium

234

Ptilotus

253

Puccinellia

242

Punty Bush

260

Purple-top

270

Purslane, Small

Pussy Tails Twining

Salsola

252

Saltbush, Bladder

250

252

, Climbing

249

, Fan

249

249

251

, Pop

, Ruby

249

, Slender-fruited

252

Salvia

, Soft-horned

252

Sandalwood 248

Sand Rocket $\quad 257$

254

254

254

Sand Spurry

257

Santalaceae $\quad 247$

247

Quandong

Santalum

247

Sapindaceae $\quad 264$

Quena

Sarcozona

254

271

Radish, Wild

257

Scarlet Pimpernel

267

Ranunculaceae

255

Ranunculus

256

Raphanus

Schismus

242

Schkuhria

281

257

Rapistrum

Scirpus

244

Scleroblitum

253

258

Raspwort,

Scolymus

281

267

Red-leg Grass

267

Reed, Common

Scrophulariaceae

271

236

241

Reseda

Sedge, Knob

243

243

258

Resedaceae

Resinweed

258

269

Rhagodia

252

Rhodes Grass

237

Ribgrass

273

Ribwort

273

Rice-flower, Small-headed

266

Rochelia, White

Roly-poly, Black

270

250

252

Romulea

$$
\text { , Soft }
$$

243

Senecio

$$
\text { , Tall Umbrella }
$$

281

Setaria 242

Shepherd's Purse $\quad 256$

Shivery Grass $\quad 236$

Sida 265

Sida, Corrugated 265

, High 265

, Pin

265

265

Silene

255

Silky Browntop 239

Silky-heads 237

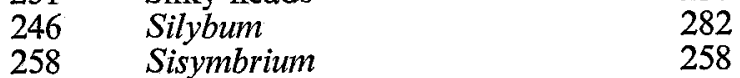

Rorippa

Sisymbrium

277

259

Rosaceae

259

Rosewood

Sneezeweed, Common

277

277 
Soapwort, Bladder

Solanaceae

Solanum

Sonchus

Sorrel,

Soursob , Yellow Wood

Sowthistle, Common , Rough

Spear Grass, Feather , Variable

Speedwell, Wandering

Spergularia

Spider Orchid, Green-comb

Spike Rush, Common Pale

Spirodela , Small

Sporobolus

Spring Grass, Early

Spurge, Desert

$$
\text { , Lagoon }
$$

Stackhousia

Stackhousia, Creamy

Stackhousiaceae

Star Bush

Starfruit

Starwort, Swamp

Stellaria , Water

Stenopetalum

Stink Grass,

Stinkwort , Smaller

Stipa

St John's Wort,

Stonecrop, Austral

$$
\text { , Matted }
$$

, Dense

, Purple

Storksbill, Long , Rufou

\section{Stuartina}

Suaeda

Sugarwood

Summer Grass,

Sunray, Musk

$$
\text { , Warrego }
$$

Swainsona

Swainsona, Downy

$$
\text { , Dwarf }
$$

Swamp Grass, Sweet

Swinecress, Lesser

Taraxacum
Tar-vine

Tea-tree, Black

Templetonia

Tetragonia

Teucrium

Themeda

Thistle, Golden

, Saffron

, Slender

, Spear

, Star

, Stemless

, Variegated

Thymelaeaceae

Thysanotus

Thornapple, Common

$$
\text { , Downy }
$$

, Fierce

, Hoary

Tiny Star

Toad-flax, Hairy

Tobacco, Tree

Toxanthes

Tragus

Trefoil, Austral

$$
\text { , Red-flowered }
$$

Trianthema

Tribulus

Tricoryne

Trifolium

Triglochin

Trigonella

Tripogon

Triraphis

Trisetum

Tumbleweed

Turnip, Wild

Turnip-weed

Tussock Grass

Twin-heads, Yellow

Twin-leaf, Pale

Typha , Violet

Typhaceae

Umbelliferae $=$ Apiaceae

Umbrella Grass,

Urtica

$$
\text { , Silky }
$$

Urticaceae

Vaccaria

Vanilla-lily, Pale , Small

Veldt Grass, Annual

Verbascum , Perennial

Verbena
253

267

262

254

270

242

281

276

276

277

276

281

282

266

245

271

271

271

271

246

272

271

282

242

260

260

254

263

245

262

235

262

242

243

243

253

256

258

241

278

263

263

234

234

268

238

237

247

247

255

245

245

238

238

272

270 


Verbenaceae
Verbena, Common
Veronica
Vetch, Common
Vicia
Viola
Violaceae
Violet, Purple
Vittadinia
Vulpia

Wahlenbergia

Wallaby Grass, Brown-backed

$$
\text { , Ringed }
$$

, Small-flowered

Water Ribbons

$$
\text { , Swamp }
$$

Waterbush

Waterbuttons

Waterwort

Water-milfoil,

Waterpepper

$$
\text { , Coarse }
$$$$
\text { , Red }
$$

Wattle, Broad-leaved,

$$
\text { , Prickly }
$$

, Western Black

, Western Silver
270 Wheat Grass, Common 235

270 White-top 237

272 Wild Oat 236

262 Wilga 263

262 Willow-herb, Hoary 267

266 Willow, Native 260

266 Wilsonia 269

266 Windmill Grass, 237

282 , Curly 237

243 Winter Grass 241

Wireweed 248

274 Wire Grass, Brush 236

237 Woodruff, Common 273

237 , Twin-leaved 273

237 Woolly Mantle 278

236 Woolly-heads 281

235 Woollybutt Grass 239

273 Xanthium 282

265 Xanthorrhoeaceae 245

267 Yam 280

$\begin{array}{lll}267 & \text { Yam } & 259\end{array}$

267 Yellow Tails $\quad 254$

248 Yorkshire Fog 239

260 Zehneria 274

259 Zygophyllaceae 263

259 Zygophyllum 263 